\title{
الدلالات التمييزية لإختبارات مجال التجهيز البصري المكاني ببطارية (NEPSY-2) لدي ذوي صعوبات تعلم الرياضيات من تلاميذ الصف الرابع الابتدائي
}

\section{حنان ممروح الصاوي طلبة}

استهدف البحث الحالي دراسة الدلات التصييزية لإختبارات مجال التجهيز البصري الدكاني

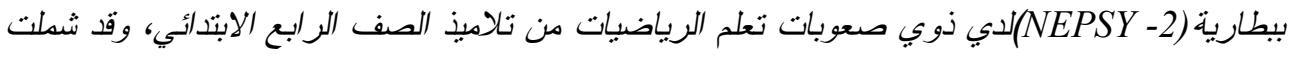

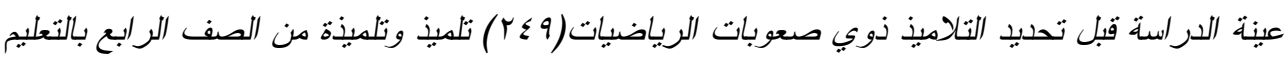

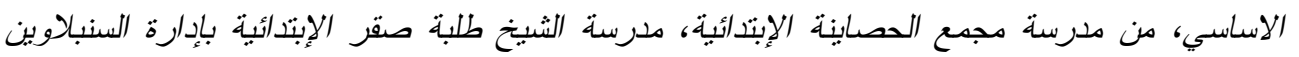

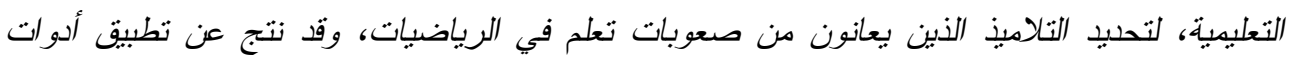

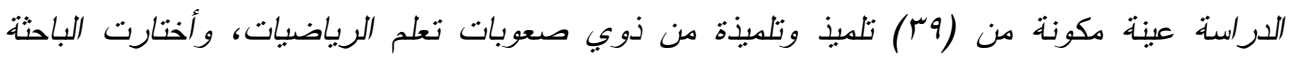

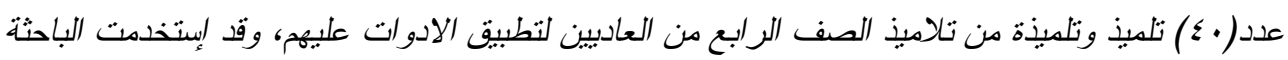

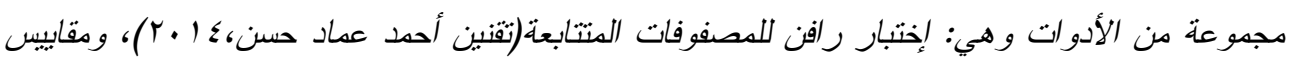

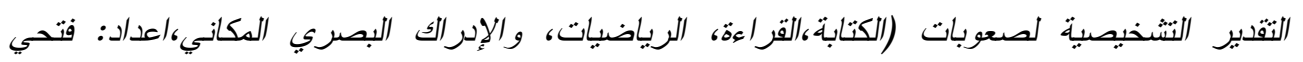

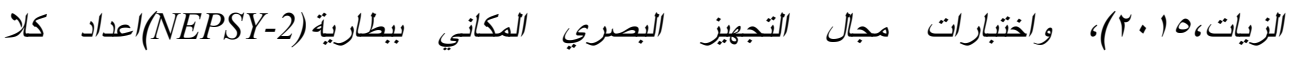
من(Korkman, Kirk, \& Kemp, 2007)، اختبار تشخيصي في مادة الرياضيات(اعداد الباحثة) لتحديد

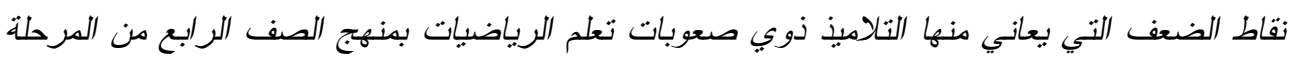
الإبتدائية، وقد أظهرت نتائج البحث التالي انه: 1 - توجد فروق بين منوسطات درجات التلاميذ ذوي صعوبات تعلم الرياضيات وبين أقرانهم العاديين

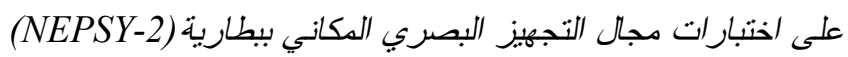

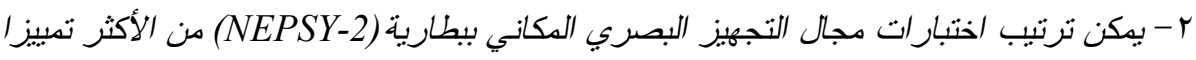

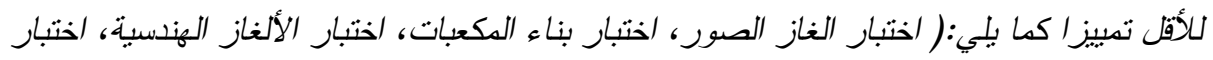

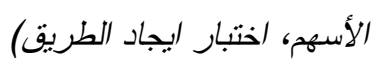

الكلمات المفتاحية: الدلالات التمبيزية، صعوبات تعلم الرياضيات ، التجهيز البصري المكاني.

\section{Abstract:}

The present research aimed at studying Discriminatory evidences of visual spatial processing tests of the (NEPSY-2) battery for students with mathematical learning disability in fourth graders. The study sample included( 249) students of fourth grade in basic education, From the elementary school of Al-Hassayneh Elementary School, Sheikh Tolba Sakr Primary School, by the Sinbillawin 
Educational Administration, to identify pupils with mathematical learning disability. The study tools were implemented by a sample of (39) students with mathematical learning disability, The researcher chose( 40) ordinary students of fourth-grade to apply the tools, The researcher used a number of tools:( Raven's test of successive matrices (codification of Ahmed Imad Hassan, 2014), and( diagnostic measures for the disability of writing, reading, mathematics, and And visual spatial perception Prepared by: Fathi El-Zayat), NEPSY-2 field tests (Korkman, Kirk, \& Kemp, 2007), a diagnostic test in mathematics (Prepared by: the researcher) to identify the weaknesses of students with The difficulties of learning mathematics in the fourth grade The results of the following study showed that:

1-There are differences between the average scores of students with mathematical learning disability and their peers on the tests field of field optical equipment (NEPSY-2).(

2- (NEPSY-2) field tests can be arranged with the least discriminating discrimination as follows: (picture puzzles test, block conistraction test,geometric puzzles test, arrows test, roat finding test)

Keywords:Discriminatory evidences, mathematical learning disability, visual spatial processing.

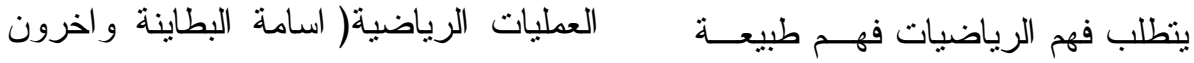

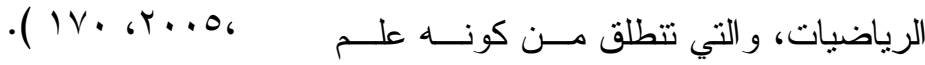

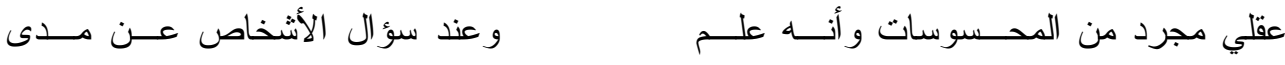

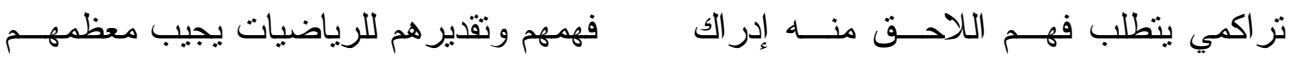

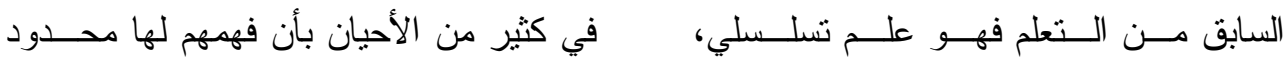

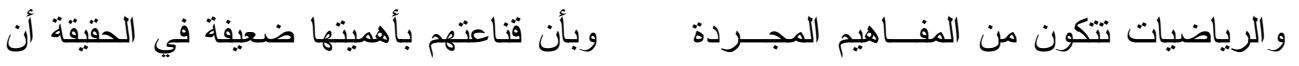

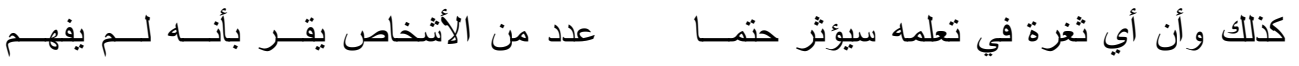

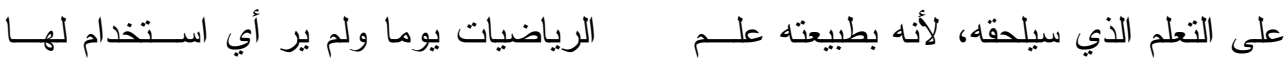

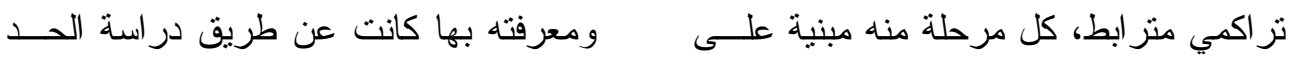

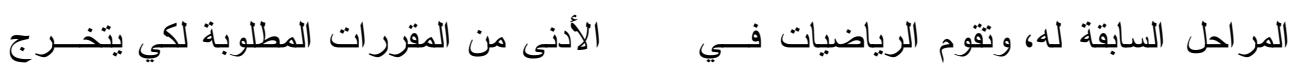

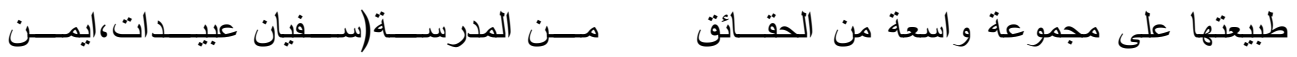

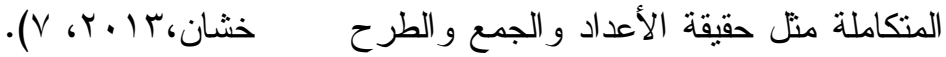

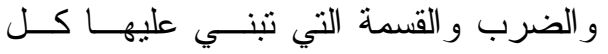


من أنماط تو اصل وتعايش الإنسان، من حيث التفكير و الاستدلال الحسابي و إدر الك العلاقات

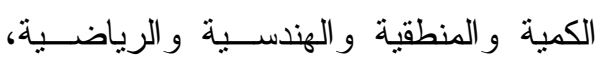

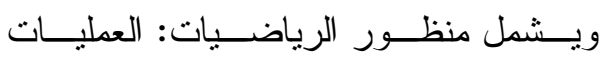

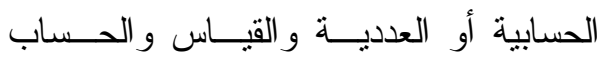
و إجر اء العمليات الحسابية و الهندسة و الجبــر إلى جانب القدرة علــى التفكيــر باســـتخدام المفاهيم و الرموز الكمية وقد لوحظ أن العديد بالي من الأطفال و الطلاب يجدون صعوبات حادة

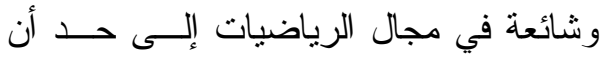

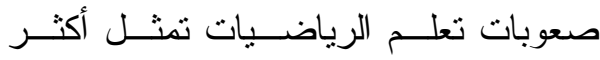
صعوبات التعلم أهمية وشيوعا، و اســتقطابا

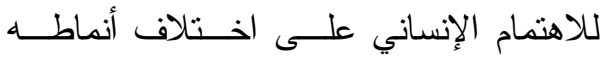
وتوجهاته(فتحي الزيات ، 1991). ومع انتشار ظاهرة صعوبات الــتعلم بشكل خاص وصعوبات تعلـــم الرياضــيات بشكل خاص بين تلاميذ المرحلة الابتدائيــة،

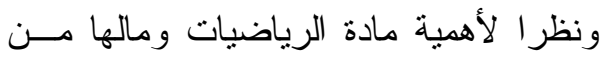
تأثنير علي العملية التعليمية بأكملها من ناحيــة، و علــي

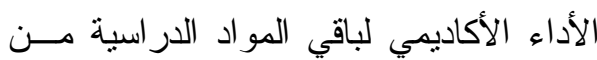
ناحية أخرى، لذا لغرض هذا البحث، ستقوم لإني

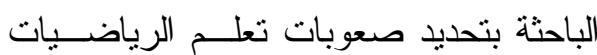

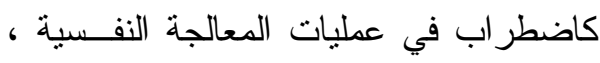

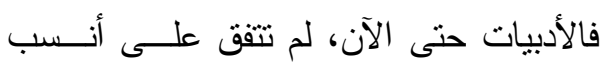
طريقة لتحديد هذه الصعوبات ،وقديما كــان يتم تشخيص ذوى صعوبات التعلم بالاعتماد
وتشير الدر اســات و البحــوث لكــلا من(Berch \& Mazzocco 2007) إلى أن صعوبات تعلم الرياضيات لم تحظ بالاهتمام

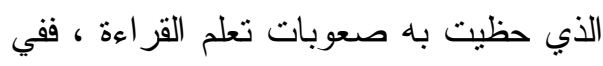

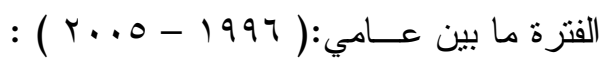
أي خلال عشر سنوات ، فاقــت در ســـات

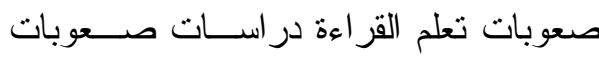
تعلم الرياضيات بما يصل بالنسبة بينهما إلى بـ

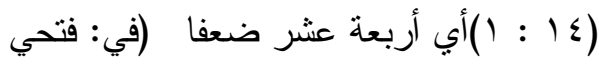

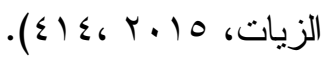

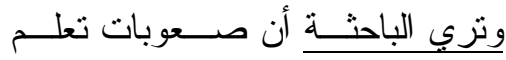
الرياضيات تعتبر مشكلة مجتمعية وتربويــة

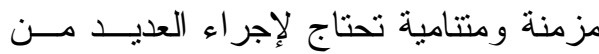

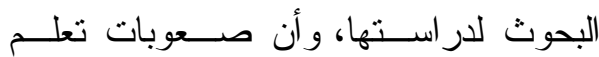
الرياضيات تعتبر علية معرفيــة إدر اكيــة

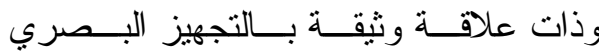
المكاني، ذلك نظر ا لأن صـــوبات الــتعلم يكون سببها الأساسي وجود خلل في الجهاز العصبي المركزي، وأنها مشكلة يعانى منها

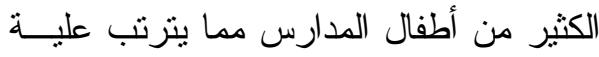

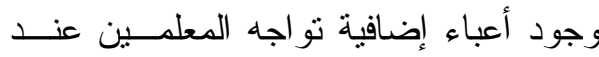
التعامل مع ذوى صعوبات تعلم الرياضيات.

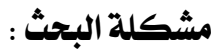

تمنتل الرياضيات لغة رمزية عالميـــة

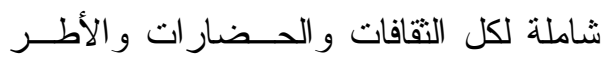
النقافية على اختلاف تتو عها وتباين مستويات تقدمها. و الرياضيات كلغة هي الأساس للكثثر 
r- تــشير بعــ الدراســات العربيــة

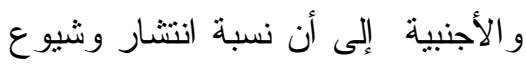
صعوبات تعلم الرياضيات في المرحلة الابتدائية على النحو التالي: توصــلت در اسة محمد البيلي و أخرون (1991 ) و التي تمت في دولة الإمار ات أن نسبة

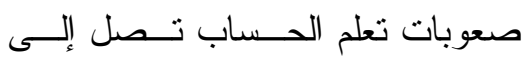
\% \% من تلاميذ الصف السادس

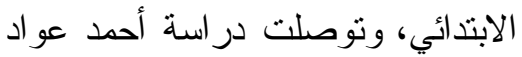

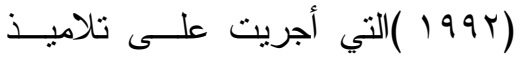

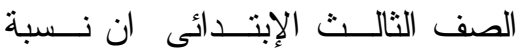
انتشار صعوبات تعلم الحساب تـصل

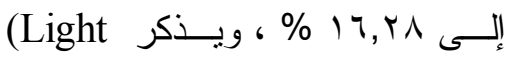
\% • • Dfries,1995 ) مــن ذوى صــــوبات الــتعلم لــديهم

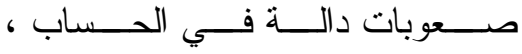
بـذكر (1999) , 19ate)

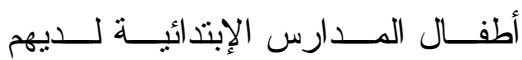
صعوبات دالة فى الحساب(في: فتحــي الحي

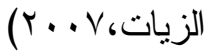

ويـشير (Clifford ,2008) إلـى أن هنالك علاقــة بـين صـــوبات تعلــم

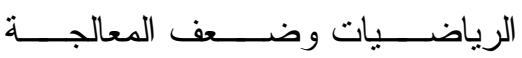
البصرية-المكانية، ولكى يــتم الفهــ

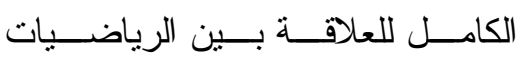

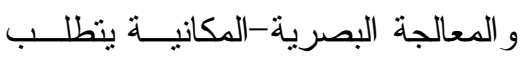

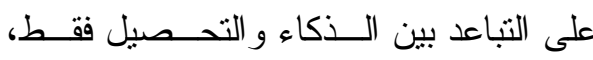

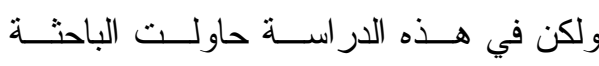
استخدام التجهيز البصري كنوع من أنــواع لـواع

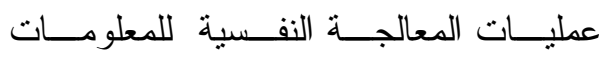

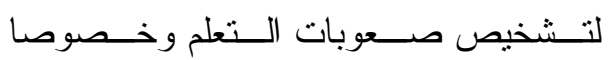
صعوبات تعلم الرياضيات باســتخدام أدوات تتخيصية جديدة.

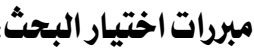

1- يعد البحــث فـي صــوبات تعلــم

الرياضيات بطيئا إذا ما قورن بالبحث

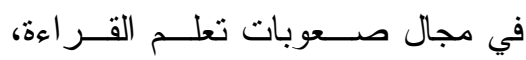
فصعوبات تعلـــم الرياضــيات تعنبـــر مشكلة مجتمعية مزمنة ومتتامية تحتاج لإجر اء العديد من البحوث لدر استها. r- يترتب على تــرك هــــه الــصعوبات و إهمالها أكاديميا حتى يصل الطفل إلى لى لـ سن الثانية عشرة ،أن ينمو لديه شعور لهادي

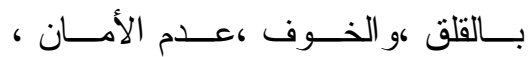

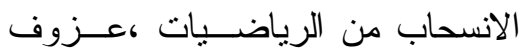

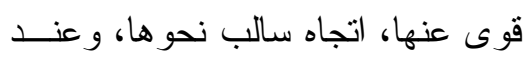
هذه النقطة تصبح أعر اض صــعوبات تعلم الرياضيات أعر اض سببية ويدخل

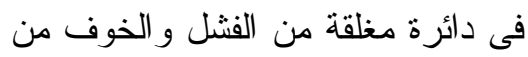
الرياضيات ،وتجنبها و اختيار مجالات تربوية يتفادى من خلالها الرياضـــيات

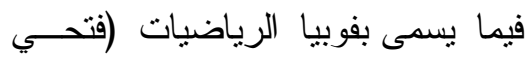

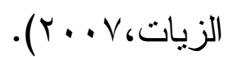


أهداف البحث: يهدف البحث الحالي إلى:

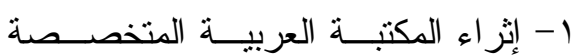

بوسيلة تشخيصية عالمية جديــدة لفئــة

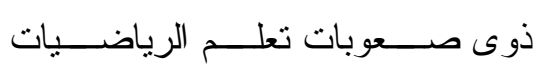
بالمرحلة الابتدائية.

r- التعرف على كفاءة اختبار ات التجهيـز

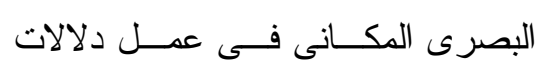

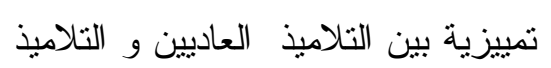
ذوى صعوبات تعلم الرياضيات .

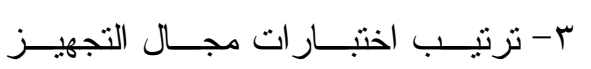
البصري المكاني ببطاريــــ- NEPSY

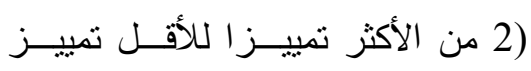
التشخيص صعوبات تعلم الرياضيات. أهمبة البحث : يستمد البحث الحالي أهميتـــ من:

1- اهمية مادة الرياضيات و اهميــة بنــاء

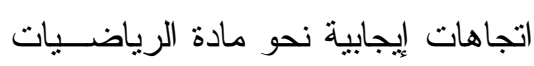
لاى تلاميذ المرحلة الابتدائية.

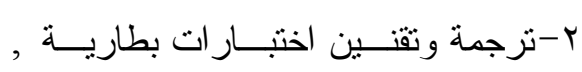
(NEPSY-2 2007)

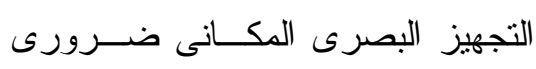
للبيئة العربية بــصفة عامـــة و البيئـــة المصرية بصفة خاصة وهــى حاجــة

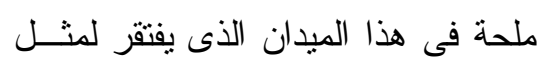

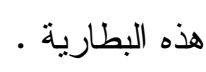

ذلك إجراء العديد من البحوث فى هذا الصدد.

ع- افتقار المجال إلى أدوات تثخيــصية

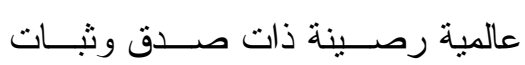

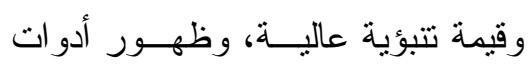

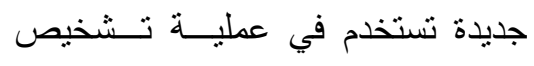

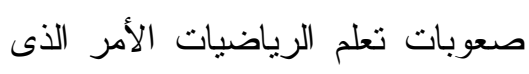

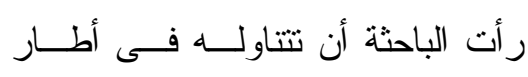

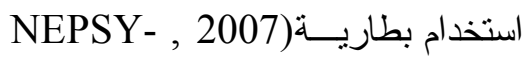

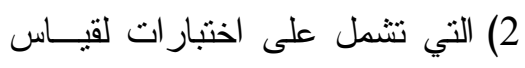
التجهيز البصرى المكانى التي تعتمــد

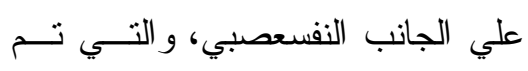

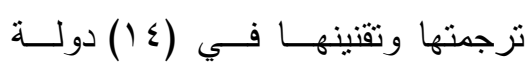
اجنبية.

وتتمثل مشكلة البحث في السؤال الرئبـسي التالي: 1 - هل توجد دلالات تمييزية لاختبـار ات

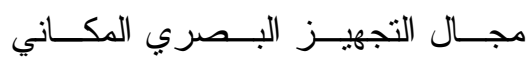
ببطاريسـة (NEPSY-2) لــدي ذوي

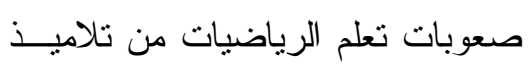
الصف الر ابع الابتدائي.

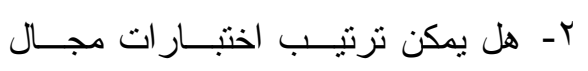

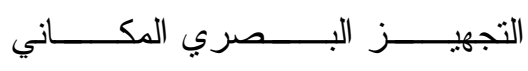
ببطارية(NEPSY-2) مــن الأكثـر تمييز اللأقل تمييز ا. 
وتعرف المعالجة البصرية المكانية بيطارية نيسي بأنها القدرة على فهم التوجه المكاني للمعلومات البصرية في مسـساحة ثنائيـــة أو ثلاثية الأبعاد، وتكمن هذه القدرة في قـدرة الثخص علي تصور الخريطة الذهنية مـنـ العناصر في ثلاثة أبعاد، وتقــدير مـسـافات

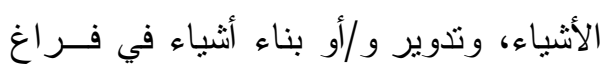
ثلاثي الأبعاد، وقد تؤدي صعوبات المبات المعالجة بناء

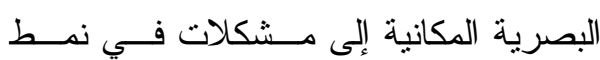

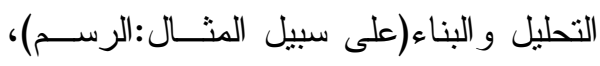
وتقدير المسافات وتوجيه الأثنياء في البيئــة، وتحديد الزوايا، وإيجاد الطريق (أي اتجاهات

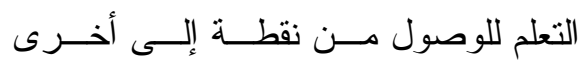
(Korkman, Kirk, \& Kemp, 2007 a).

r- التلاميذ ذوي صعوبات تعلم الرياضيات "pupils with Dyscalculia "

يعرفهم (السيد صقر ، 10 • ب، 79):

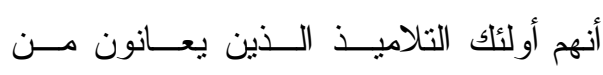
صعوبات تعلم خاصة أو نوعية في الحساب (Dyscalculia)

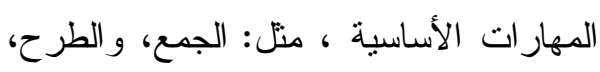

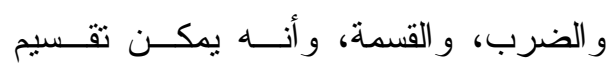

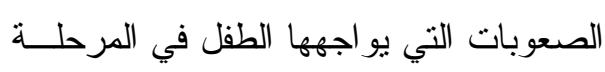
الإبتدائية في مجال إجر اء العمليات الحسابية،

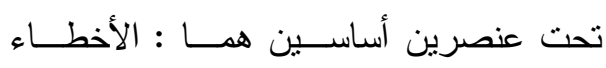

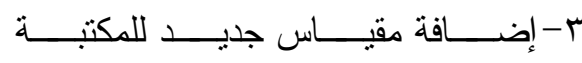

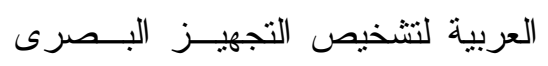

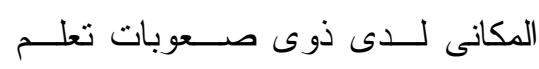
الرياضيات.

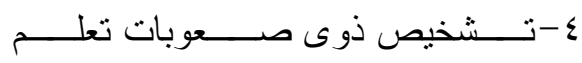

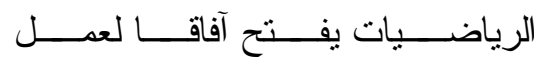

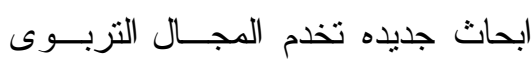

بوجه عام ومجال صعوبات التعلم بشكل خاص. المفاهيم الإجر ائية للبحث:

ا Discriminatory evidences

يعرف فتحي الزيــات(*) الـــلالات

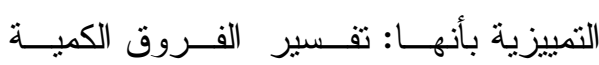
الناتجة عن الدلالات الإحسـصائية بــصورة كيفية .

\section{r - إختبار ات مجــال التجهــز البـصري المكاني بنطارية (NEPSY-2):}

هي مجمو عة الاختبار ات المسـتخدمة في تشخيص صعوبات التجهيـز البـصري

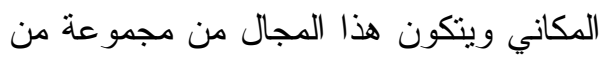

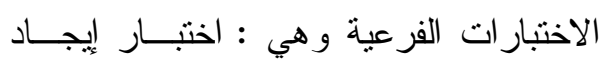
الطريق، و اختبار الأســـهم، و اختبـــار بنـــاء

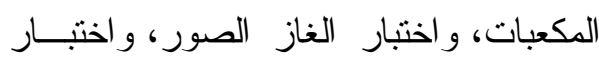
الألغاز الهندسية.

* مناقثة علمية مع سيادنه بتاريخ 9 // /7 1 • ؟. 
ع- حدود مكانية : وتتمنل في مدرسة مجمع

الحصاينة الابتدائية، ومدرســة الـشيخ

طلبة صقر الابتدائية بإدارة الــسنبلاوين

التعليمية بمحافظة الدقهلية .

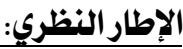

أولا :التجهيز البصرى المكانحى:

هناك أنواع عديدة لأساليب معالجــة

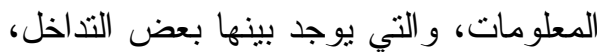

ولكن يوجد اثثين من هذه المجالات الهامــة

و الحرجة و هما المعالجة البصرية و المعالجة

السمعية، ووجود اضطر ابات في و احـدة أو

أكثر من هذه المجالات بمكن أن نؤثز على ولى

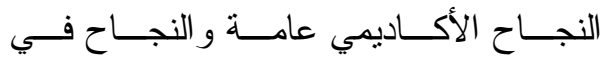

الرياضيات خاصة(الباحثة).

وتثير الأدبيـات أن هنــاك نوعــان مـن المعالجة البصرية-المكانية:

أ) المعالجة البــصرية المكانيـــة الفعالـــة:

تتمل تلقى المعلومــات البـصرية-

المكانية أثناء تحويلها أو معالجتها أو لتولهئ

إستغلالها.

ب) المعالجة البـصرية-المكانيــة غيـر

الفعالة: تسترجع المعلومات التـي لانه لهانه

تتطلب أي معالجة أو تعديل، و الدليل

على هــذا التفريسـق بـين الــذاكرة

البصرية-المكانية الفعالة وغير الفعالة

يأتي من تقييم الاختلافات في المعالجة
و الصعوبات المرتبطة بالحقــائق الأساســية

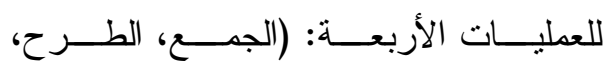

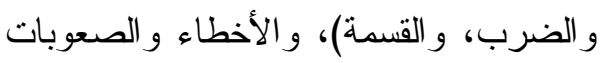

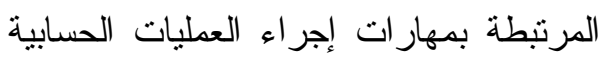
و التي ترنبط بإجر اءات الحل وتسجيله.

حدود البحث: تتمنك محددات البحــث فـي

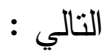

1- حدود موضوعية : وتتمنل في متغيرات

$$
\text { الار اسة وهي: }
$$

أ - اختبار ات التجهيز البصرى المكانى

ب - صعوبات تعلم الرياضيات .

r- حدود بشرية: وتتمنل في عينة الدراسة،

و التي تكونت من (V9) تلميذا وتلميــذة ولنه

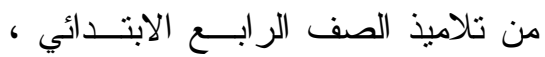

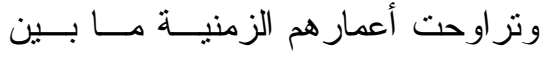

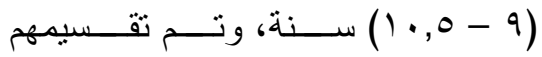

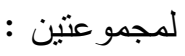

أ - مجموعة التلاميذ ذوى صـسعوبات

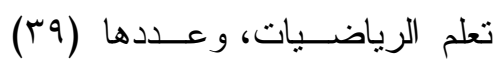

$$
\text { تلميذا وتلميذة. }
$$

ب - مجموعـــة التلاميــــ العـــاديين، و عددها ( • ع) تلميذا وتلميذة.

r- حدود زمنية : وتتمتل في فترة تطبيـق

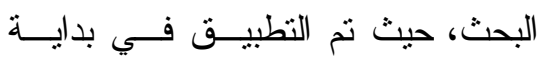

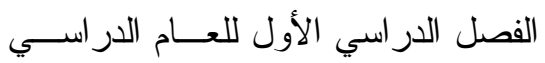




$$
\begin{aligned}
& \text { للمثير المــادي) التــي يــتم تــشكيلها مــن }
\end{aligned}
$$

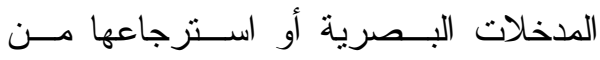

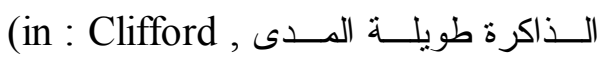

$$
\begin{aligned}
& \text { 2008) } \\
& \text { ويذكر (فتحي الزيــات،م . . ץ، } 90 \text { 1- } \\
& \text { 197 ) انه قد صنفت العديد مسن الدراســات } \\
& \text { و البحوث التي أجريــت حــول الخــصائص } \\
& \text { السلوكية لذوي صعوبات التعلم غير اللفظية } \\
& \text { هذه الخصائص إلى أربع مجموعات هي: }
\end{aligned}
$$

ا • بصري/ مكاني : Visual / spatial r.

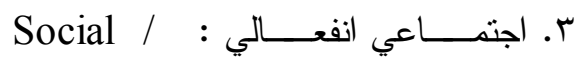
emotional

ع. أكاديمي Academic وســنتناول منهـــا بالتفصيل مجموعة الخصائص الــسلوكية

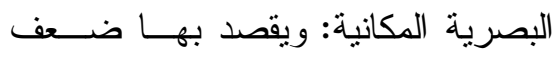

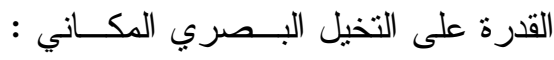

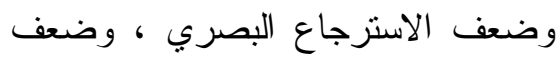
الإدر الك المكاني ، وصعوبات في الانتبرهاه

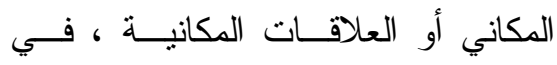
المو اقف المدرسية : مثل : 1 ـ صعوبات مع المدركات المكانية

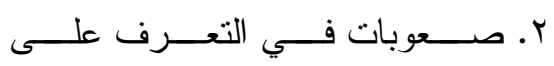
المعلومــــات البــــصرية المكانيــــــة وتتظيمها r. صعوبات فــي الــذاكرة البـصرية و التصور البصري .

$$
\begin{aligned}
& \text { البصرية-المكانية عند كبــار الــسن. }
\end{aligned}
$$

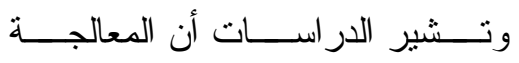

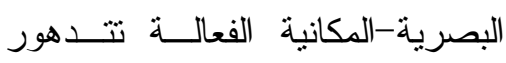

$$
\begin{aligned}
& \text { خلال سن الثيخوخة، فـي حـين أن } \\
& \text { المعالجة البــصرية-المكانيـــة غيــر }
\end{aligned}
$$

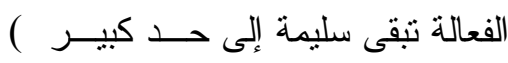$$
\text { .Reuhkala, 2001,390) }
$$

ونتشير بحوث كلا من (Baddeley,

1996; Pickering \& Gathercole, 2004) أن هناك علاقة بـين الرياضــيات وضعف المعالجة البصرية-المكانية، حيــث

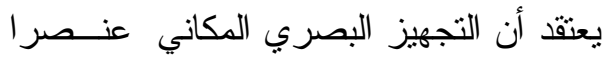
من عناصر العملية النفسية بالذاكرة العاملة، و النظرية الأكثر تحديدا للذاكرة العاملة فــي بــي الأدب، هي نظرية آلان باديلي حيث تقـسم

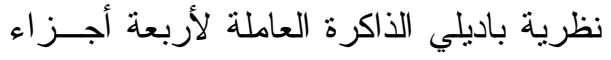

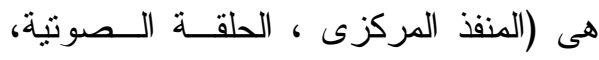
الوحدة البصرية-المكانية و المخزن المؤقت

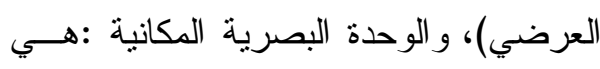

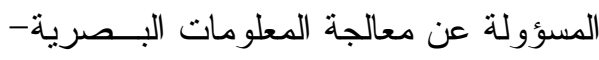

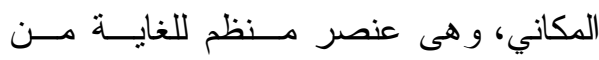

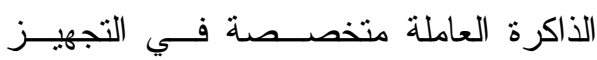
و المحافظة على المعلومــات التــي توضــح

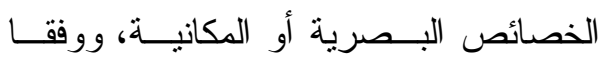
لنموذج بادلي فإن الوحدة البصرية المكانيـــة هي مركز تخزين محدود المدى للتمثـيلات للتهات العقلية (مثل الخصائص البصرية المكانيــة 
الأجسام فى الفر اغ و القدرة علـــى اختز انهــــا

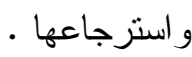

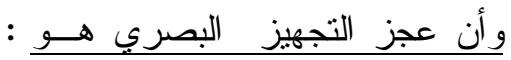

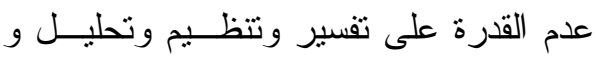

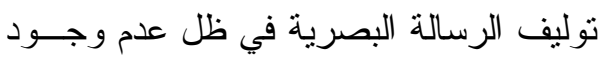

$$
\text { ضعف البصر • }
$$

ثانيا بطارية (NEPSY-2, ث) (NEPSY-2)

Korkman, Kirk,\& Kemp,2007)

هي الإضـافة الثانية إلــي المقيــاس

النفسعصبي المطور حيث تشمل (NEPSY)

Korkman, Kirk, \& Kemp, ) الأصـلية

1998) الذي احتوي على rV اختبار فرعى ه ع

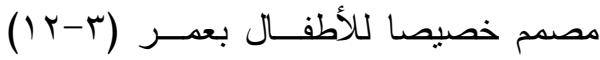

لتقيس 0 مجالات :"الانتباه السمعي و الوظيفة

التنفيذيـــة ، ومجــــال اللغــــة ، و المجــــال

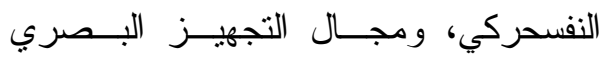

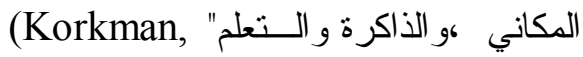
Kirk, \& Kemp, 2007 a).

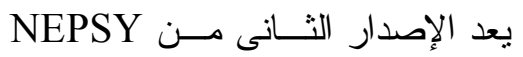

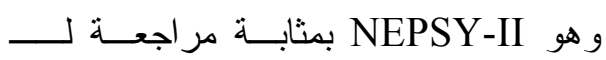
NEPSY

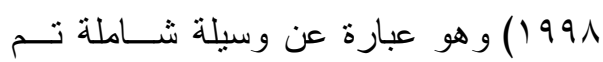

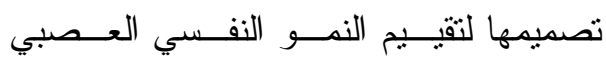

للأطفال في مرحلة ما قبل المدرسة وفى سن

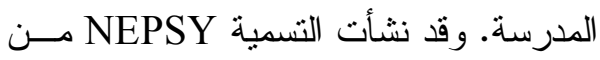

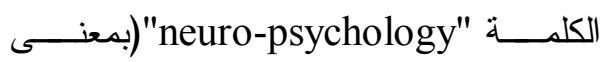

نفسي عصبي) من الحروف الأولى لكل من
ع. صعوبات فــي التــداخل البـصري

المكاني

0. صـــعوبات فــي إدر الك الــصيخ أو

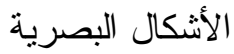

T. صعوبات مع خر ائط المفاهيم

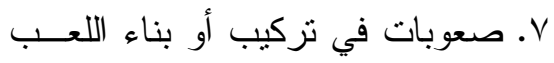

$$
\text { أو المكعبات }
$$

^. صعوبات في التعامل مع الدـساحات

$$
\text { المكانية }
$$

( Johnson, ويعـرف كــلا مــن

Humphrey, Mellard, Woods, \& Swanson, 2010)

البصري : بأنه صعوبة تعلم لــدى الطفـلـل حيث يجد صعوبة في فهم وتذكر مـــا يــر اه حيث يميل الطفل إلى فقدان مكانه في الكتابة

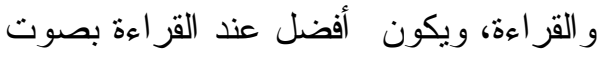
عال وتكون الخــر ائط و الرســـوم البيانيــة صعبة، وتتضمن المعالجة البصرية (التمييز

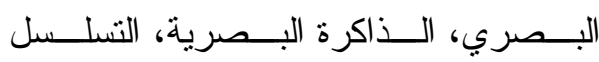
البصري، الإغلاق البصري، سرعة التجهيز البصري، العلاقات المكانية)

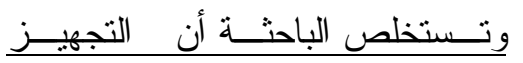

البصري هو : عملية عقلية معرفية يتم فيهـا

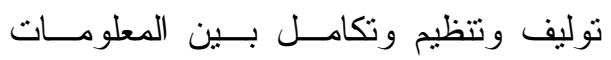
البصرية الجديدة و المعلومات الـسابقة فــي ولي أنماط ذات معنى وفهم كيف يمكن أن تدور 
وأيضا تم إضافة مجال جديد بالإضافة إلـى

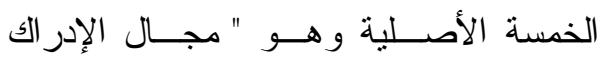
الاجتماعي"، وتمت إضافة بعض الاختبار ات الاتو الإن

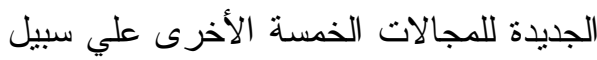
المثال: تمت إضافة كلا من (اختبار الألغــاز

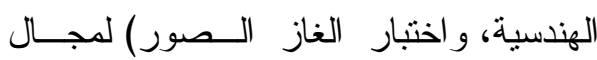
التجهيز البصري المكاني.

ونتيجة بطارية(NEPSY-2) كاملـــة

تعطى فكرة نسبية عن مناطق القوة ومناطق الضعف عند الطفل وتستخدم لتفسير التجهيز المعرفي عند الطفل، بالإضـافة إلــى تــوفير

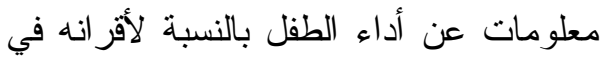

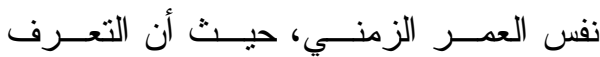
و الثر ح للأضر ار المعرفية العصبية للطفــل يمد بأساس ثابت لعمـل توصــــات التـــخل لتحسين الوظائف فــي المدرســـة و المنــزل و السياق الاجتماعي وهى أداة شاملة صمدت

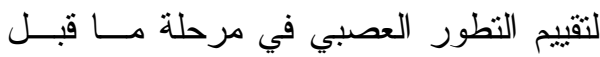
المدرسة ،ويوضــح جـدول(1) مسـسميات

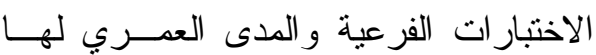
وماذا تقيس ببطارية ( NEPSY-2) و التـي ولي قامت الباحثة باستخدامها في هذا البحث.
"Psychology" و "Neuro" كلمن وتساعد النتائج التي ينم الحصول عليها مــن تقييم NEPSY-II في التشخيص وتخطبط

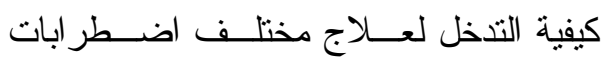
الأطفال. وبصفة خاصة، يوفر NEPSY-II

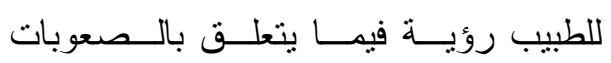

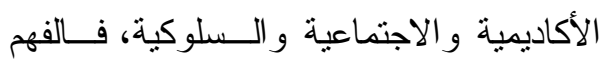
الثامل لنقاط القوة و الضعف المعرفية لــدى الـى الطفل يمكن أن يسكل تطوير خطط تعليميــة

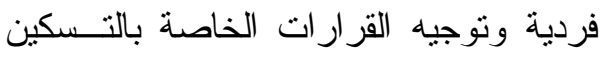
و التدخل (Korkman, Kirk, \& Kemp). 2007, b)

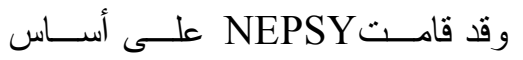

النظرية الطبيــة للوريــا، وعلـــى التـــراث

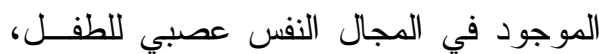
وقد نم تصحيح (NEPSY -2) و اتسسعت لتكون أداة نفسعصبية أكثر حساسية واشتمالا ؛ حيث انسع مستوى العمر الزمني في (2) ليشمل من (rEPSY من(T-Y I ( سنة، حيث إن معظم المقــاييس

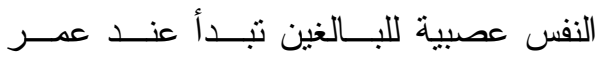

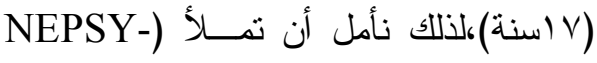
2)الفجوة الناقصة في المقاييس النفسعصبية، 


\begin{tabular}{|c|c|c|c|c|}
\hline الوصف & الأعمار & الإختصار & الإختبار الفرعي & المجال \\
\hline 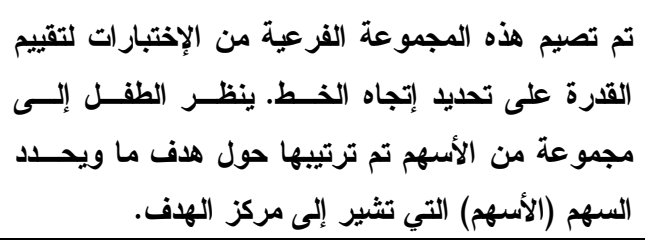 & $17-0$ & $\mathbf{A W}$ & الأسهم & \\
\hline 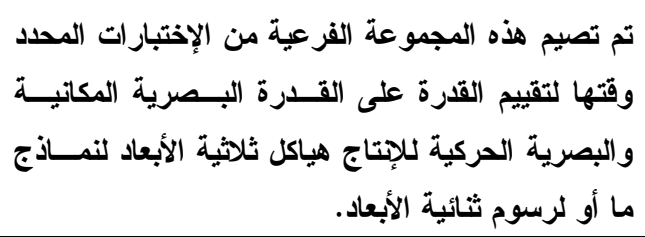 & $17-r$ & BC & بناء المكعبات & \\
\hline 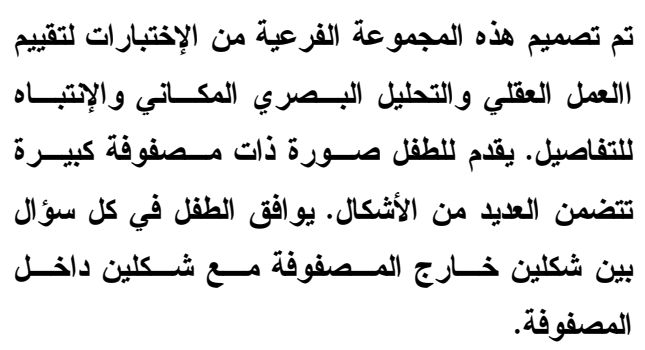 & $17-r$ & GP & الألغاز الهندسية & $\frac{E^{2}}{E}$ \\
\hline 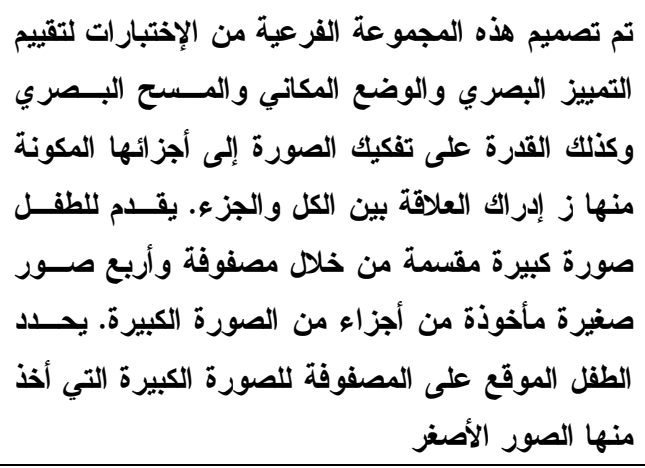 & $17-V$ & PP & الألغاز المصورة & $\varepsilon$ \\
\hline معرفة القد تصديم هذه المجموعة الفرعية من الإختبار ات لتقييم & $1 r-0$ & RF & إيجاد الطريق & \\
\hline
\end{tabular}

(Korkman, Kirk, \& Kemp, 2007 a). 
ثالثا :صعويات تعلم الرياضيات :

ا - صعوبة في الربط بين الــرقم و الرمــز

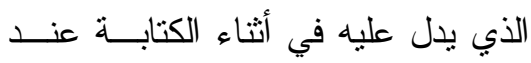

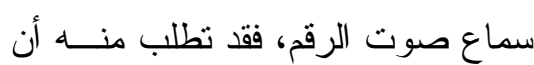

يكتب الرقم انثين فيكتب (r).

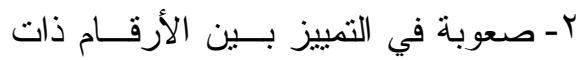

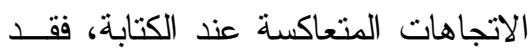

يقر أ أو يكتب الرقم (T) على أنـــه (r)

وبالعكس، و هكذا بالنسبة للرقمين (V) و

(^)

ז- عكس الأرقام الموجودة في الخانــات : فئات

فتطلب منه كتابة ( اثثا عثر )، فيكتبهـا

ع- صعوبة في استيعاب المفاهيم الأساسية

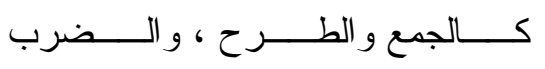

$$
\text { و القسمة . }
$$

0ـ القيام بإجر اء أكثر من عملية حسـابية

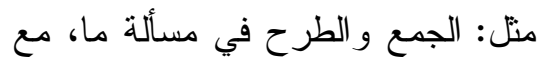
أن المطلوب مثنا هو الجمع فقط.

وتشمل أدوات تــشخيص صـــوبات

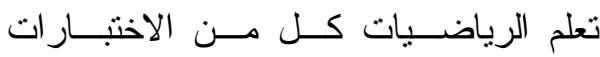

و المقاييس المعياريـــة المرجــع و المحكيــة

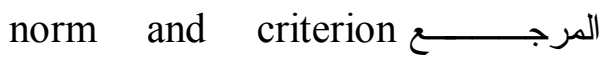

ومن الاختبار ات و المقاييس معيارية المرجع

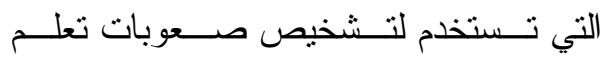

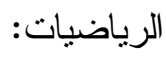

تعتبر صــعوبات تعلــــم الرياضـيات

مشكلة مجتمعية مزمنـــة ومتتاميــة تحتـــاج لإجر اء العديد من البحوث لدر استها.

فقد نجــد تتــاقض بــين مسـستويات

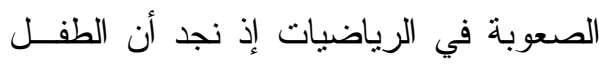

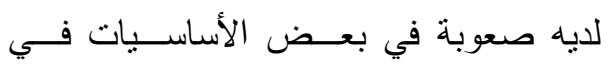

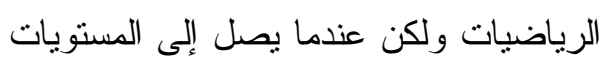

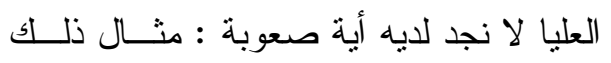

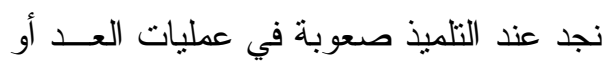

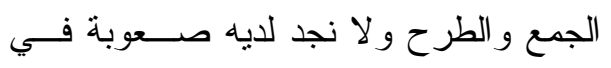

العمليات العليا مثل جمع الكسور وضــربها

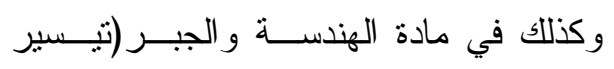

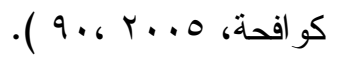

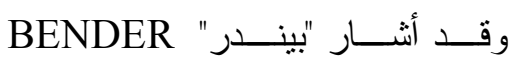

(2005) إلي أن الرياضيات ربما تكون مـنـ

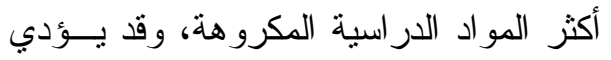

ذلك إلي تكوين حاجز نفسي أو عائق انفعالي

يعوق التحصيل الناجح في مادة الرياضــيات وينبغي علي المعلمين مساعدة طلابهم فـي في لردي

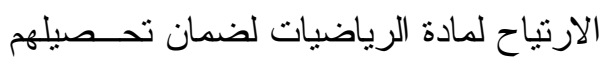

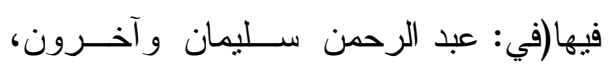

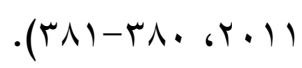

ويشير (حسني شنيوي، ابتشام محمــد،

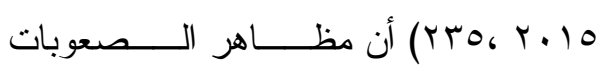
الخاصة بالرياضيات تتمنل فيما يلي: 
العلاقة بين الصور البصرية والقدرة المكانبة

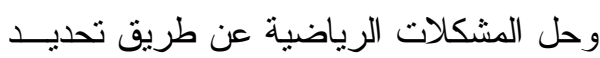

نوعين مختلفين من التمثـ بلات البــصربة -

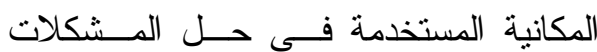
الرياضية، و هما( التمثت بـلات التخطيطبــة،

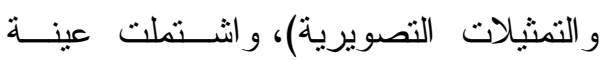

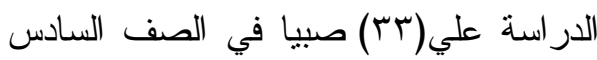
الابتدائي بمدرسة دبلن الابتدائيــة بأيرلنــــــا،

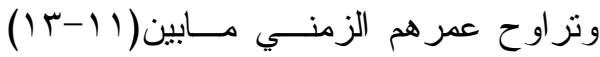
سنة، واستخدم الباحث مجموعة من الأدوات

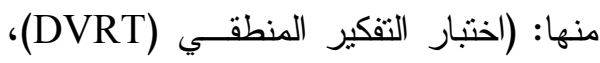

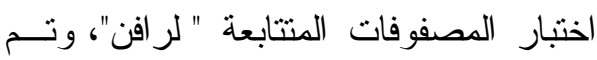
قياس القدرة المكانية بواسطة اختبارين، بناء

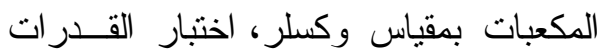
العقلية لنزستون، و اسفرت نتائج الدر اسة أن

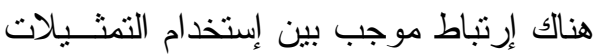

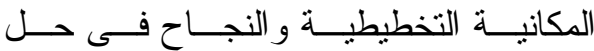
المشكلات الرياضية،فى حـين أن إبــتخدام التمثيلات التصويرية ارتبط سلبيا مع النجاح فى حل المشكلات الرياضية، وأن إبــتخدام التمثيل التخطيطى أيضـا يرنبط بشكل كبيــر مع مقياس القدرة المكانيــة، وبالتــالى فــانِ الار اسة تساعد على توضيح العلاقـــة بــين

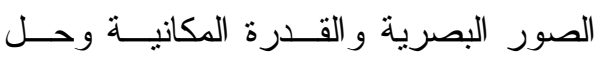

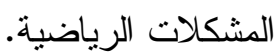

فــي حسين هـــفت دراســة كــلا

من: Assel, Landry, Swank, Smith \&
Key Maths اختبار مفتاح الرياضيات .3 - اختبار ستانفورد لنتخيص الرياضيات Stanford Diagnostic Mathematics Test

- اختبــار التقـــويم التشخيــصـي المبكـر

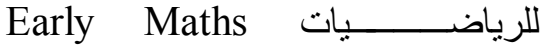
Diagnostic Assessment وبالإضافة إلى ذلك توجـــ (EMDA) العديــــــــن الاختبـــار ات و المة إيــييس

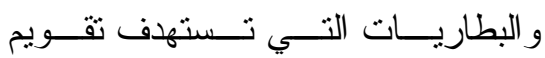
وتثخيص مكونات الرياضيات : منل : الحساب - إجر اء العمليـات الحسـسابية وغيرها ومن أمتلة هذه الأدوات : - بطارية اختبار التحصيل واسع المدى : Wide Range Achievement - اختبار ات وودكوك- جونسون للتحصيل: Battery 4 ed WART 4 Woodcock - Johnson Tests of achievements $3 \mathrm{WJ}-3$

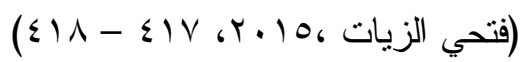

لذا حاولت الباحثة في هــذا البحــث

استخدام أدو ات تثخيــصية عالميــة جديــــة لتتخيص صعوبات تعلم الرياضيات . الدراسات السابقة: - ابق توجد عدة در اسات تتاولت صعوبات

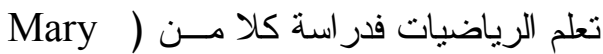
Hegarty and Maria Kozhevnikov, 1999) هدفت هذه الدر اسة الــي توضـيح 
هنالك انخفاض كبير في المعالجة البــصريةالمكانية الفعالة في الموضوعات القديمــة، و هذا يدعم الفصل بين العمليات البــصريةالمكانية الفعالة وغير الفعالة.

و هدفت در اسة ) Eldon Clifford,

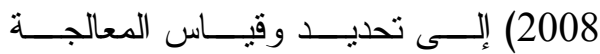

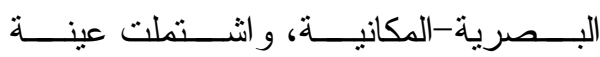

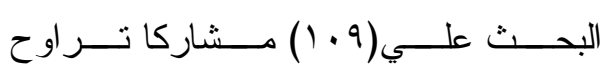

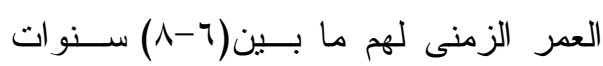

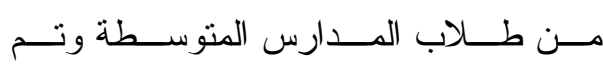

إستخدام مقياس ستانفورد بينيه للاككاء الطبعة

الخامسة (SB5)، ومقياس وكسلر - الطبعة

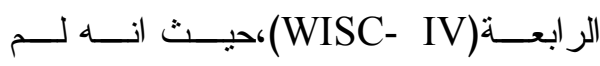

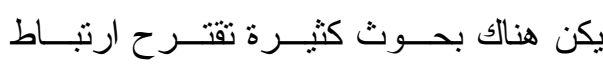

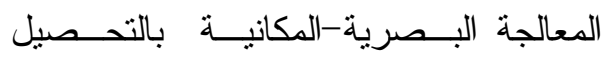

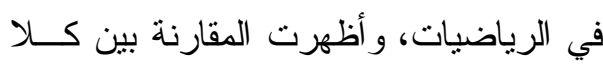

من النتائج المنتابعة و المنفصلة أن كلا من ولن

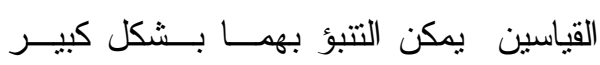
بالتحصيل فى الرياضيات.

فروض البحث : بالئ

تتلخص فروض هذا البحث في:

1- توجد دلالات تمبيزية لإختبار ات مجــال

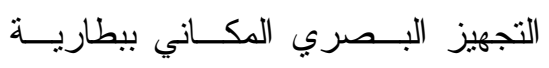

لدي ذوي صعوبات تعلم (NEPSY-2)

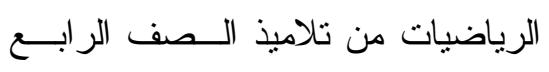

$$
\text { الابتدائي. }
$$

） （Steelman,2003)

العلاقة بين التجهيز البصرى المكانى و القدرة

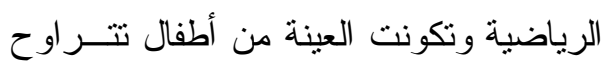

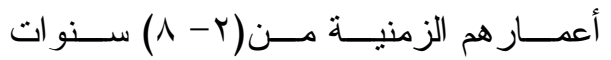

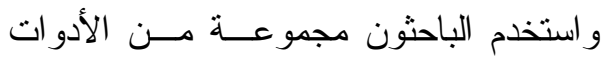
منها: إختبار إستانفورد بينيه الطبعة الخامسة

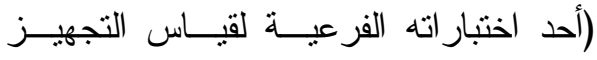

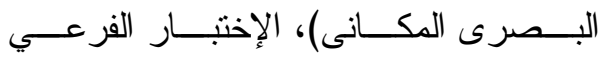

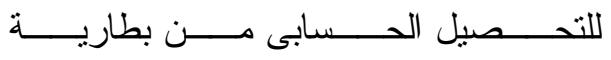
(Woodcock-Johnson )

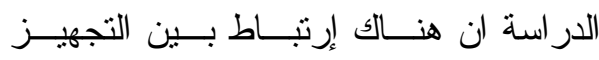

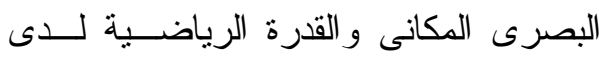

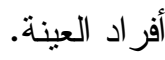

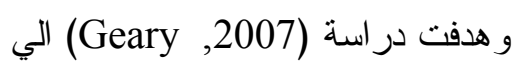
المقارنة بين المعالجــة البــصرية المكانيـــة

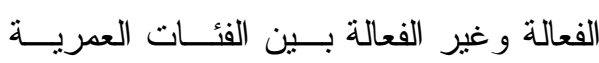

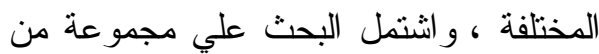

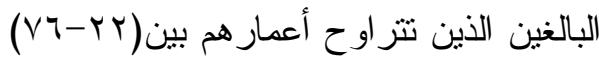
عاما، بإستخدام التقييمات سواء من الذاكرة البصرية المكانية غير الفعالة منل : (المهـام التي تتطلب فقط تذكر على المدى القـصير للمعلومات البــصرية-المكانيــة) أو المهـــام

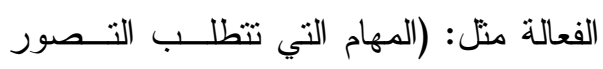

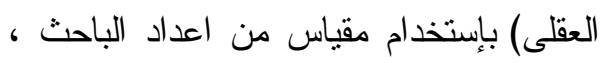

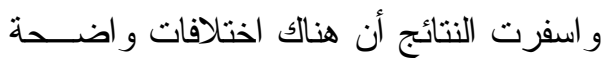
فى المعالجة الفعالة وغير الفعالة عند التقبــيم

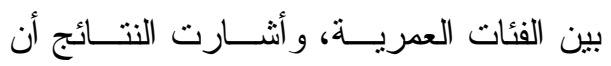


تثخيص التلاميذ ذوى صعوبات التعلم:

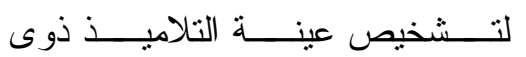

صعوبات التعلم قامت الباحثة بتحديدهم على

$$
\text { أساس ثلاث محكات وهى : }
$$

1 - محــــ الإســتبعاد: Exclusion

Criterion

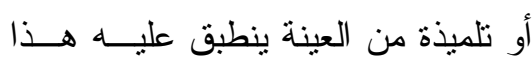

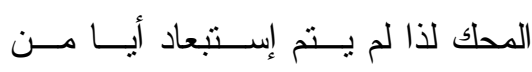

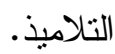

Piscrepancy : محـــ التباعـــــ Criterion وذللك عن طريق حسساب

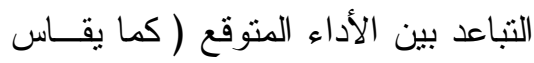

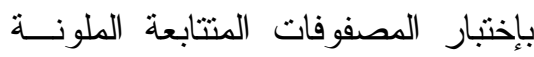
إعداد "Raven" وقنتــــه علـــى البيأـــة المصرية عماد أحمد حسن ) ، و الأداء الفعلى( كما يقاس بدرجات تلاميذ العينة

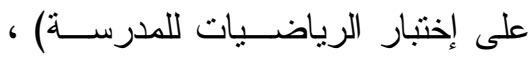
وبعد تحويل كلا من درجـات الــذكاء

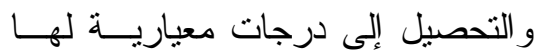

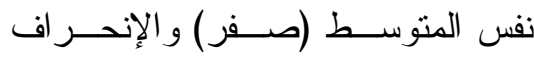
المعيارى (و احد صحيح) ، ثم حسساب الفرق بين الدرجة المعياريـــة للـــكاء

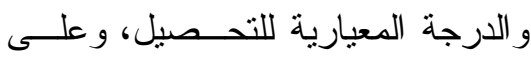
ذللك يصبح التلميذ من ذوى صــعوبات

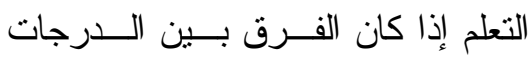
المعيارية للذكاء و الدرجات المعياريـــة الدية للتحصيل يساوى و احد إنحر اف معيارى وليه
Y- يمكن ترنيب اختبارات مجال التجهــز البصري المكاني ببطارية(NEPSY-2)

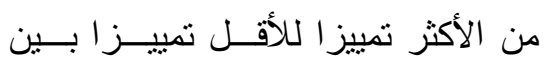

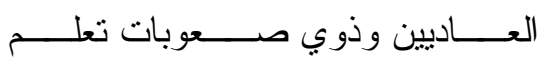
الرياضيات.

\section{منهج البحث وإجرائاته الميدانية:}

اســتخدمت الباحثــة المـــهج شــــه

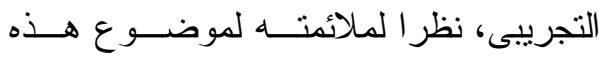

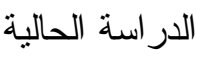
عينة البحث:

أجرت الباحثة الدر اسة الأساسية على

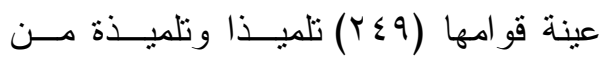
تلاميذ الصف الرابع من المرحلة الإبتدائيــة

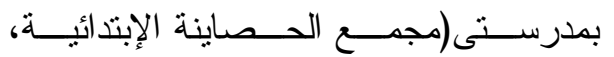
و الثيخ طلبة صــقر الإبتدائيــة) التابعتـــان لإدارة السنبلاوين التعليمية بمحافظة الدقهلية،

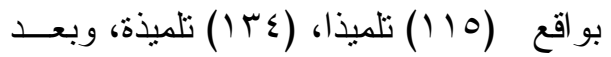
تطبيق جميع أدوات التـشخيص و إســتبعاد الذين لـــ يكملـــوا الإجابــة علــى جميــع

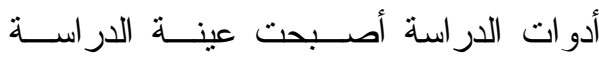

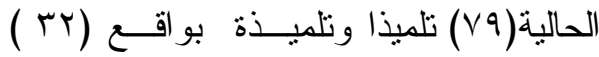

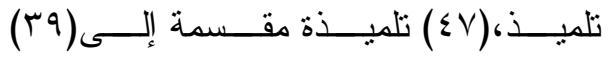
تلميذا وتلميذه مسـن ذوى صــعوبات تعطــم

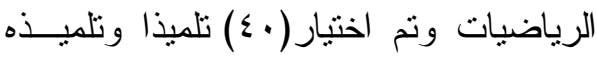

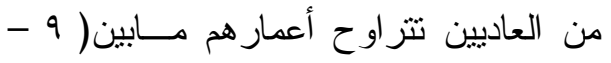

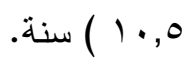


حيث شرحت الباحثة لمعلمــي مــادة

اللغة العربية ومادة الرياضبات الهدف مسـن

كل مقياس، وتم إستبعاد عــدد (Y I) تلميــذا

وتلميذة من ذوى صــــوبات تعلـــم القـــر اءة

و الكتابة لعدم شمول عينة الدر اســـة الحاليــة على هذه الصعوبات، وتم إستبعاد عدد(1) تلميذا وتلميذة اظهروا تفريط تحصيلى وفقـا لأر اء المعلميين علــي المقـــيس، وبــذلك أصـــــت العينـــة النهائيـــة للتناميـــذ ذوى

صعوبات تعلم الرياضــيات عــددها ( . ع ) تلميذا وتلميذة ثم أصــبحت عـددها (q ) تلميذا وتلميذة بسبب إنقطـاعـاع تلميــذا عــن

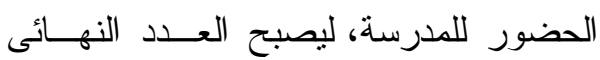

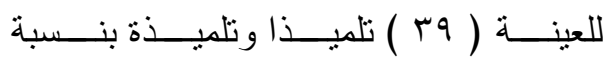
( و هذه النسبة تنو افق مع النسب العربية منـلـ

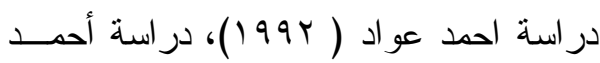

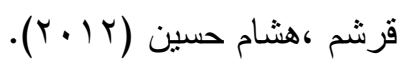

و الجدول التالى يوضـح توزيع تلاميذ عينــة

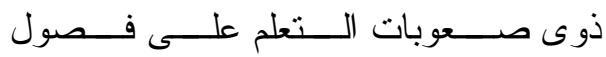
المدرستين:
أو أكثر ، ويصبح التلميذ من التلاميـذذ العاديين إذا كان الفرق بين الــدرجات المعيارية للذكاء و الدرجات المعياريــة

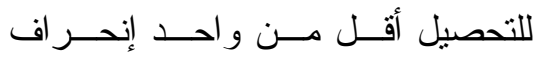
معيارى وقد بلغ حجم عينـــة التلاميــذ

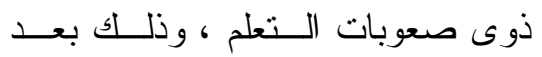
تطبيق محك التباعد بدرجات التحصيل على إختبار أخر العام بالمدرسة لــنفس

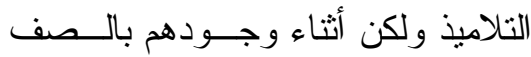
الثالث الإبتدائى.

- اسفرت النتائج عن وجود ( V. تلميذا وتلميذة) حقةـــوا التباعــــ بــدرجات تحصيل الرياضيات بالمدرسة بنـسبة .\% r^, l

r - تطبيق مقاييس التقدير التشخيصبة: وذلك لتشخيص التلاميذ ذوى التفــريط التحصيلي و الحصول على عينة نقيـة من ذوى صعوبات تعلم الرياضــيات، حيث قامت الباحثة بتطبيق كــلا مــن مقياس التقدير التشخيصى لــصعوبات

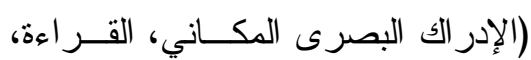

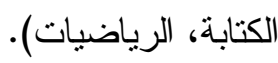




\begin{tabular}{|c|c|c|c|c|c|}
\hline \multicolumn{6}{|c|}{ جدول (ץ) توزيع التلاميذ ذوى صعويات التعلم و نتيجة الإختيار العشوائى العاديين على فصول الصف الرابع الإبتائى } \\
\hline \multicolumn{2}{|c|}{ عدد التلاميذ العاديين } & \multicolumn{2}{|c|}{ عدد التلاميذ ذوى صعوبات التعلم } & الفصل & المدرسة \\
\hline \multicolumn{2}{|c|}{$(\wedge)$} & \multicolumn{2}{|c|}{$(\wedge)$} & \multirow[t]{2}{*}{$1 / \varepsilon$} & \multirow{4}{*}{ الإبتأئية بإدارة } \\
\hline 1 1 إناث & r ب أكور & 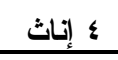 & ك إ ذكور & & \\
\hline \multicolumn{2}{|c|}{$(7)$} & \multicolumn{2}{|c|}{$(1 \cdot)$} & \multirow{2}{*}{$r / \varepsilon$} & \\
\hline r r إناث & r ب أكور & 1 & ع ذ ذكور & & \\
\hline \multicolumn{2}{|c|}{$(1 \cdot)$} & \multicolumn{2}{|c|}{$(v)$} & \multirow[t]{2}{*}{$1 / \varepsilon$} & \multirow{4}{*}{ الإبتئئية بإدارة صقر } \\
\hline 9 9 & ا ذكور & 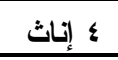 & r r بكور & & \\
\hline \multicolumn{2}{|c|}{ (14) } & \multicolumn{2}{|c|}{$(1 \leq)$} & \multirow{2}{*}{$r / \varepsilon$} & \\
\hline 9 9 & 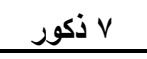 & 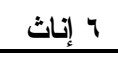 & 1 ا نكور & & \\
\hline \multicolumn{2}{|c|}{$(\xi \cdot)$} & \multicolumn{2}{|c|}{$(r q)$} & & \multirow{2}{*}{ 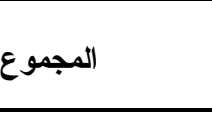 } \\
\hline 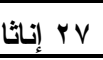 & rا ذكورا & r. & (9 اذكورا & & \\
\hline
\end{tabular}

الجمعى، وقد أعدت لكى تقيس بـشكل

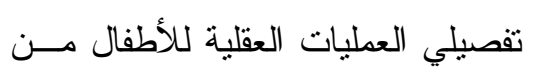

$$
\text { عمر ( 0,0 - 11) سنة. }
$$

\section{الخصائص السبكومترية للإختبار:}

حيث تز اوحت معاملات الإرتباط بـين

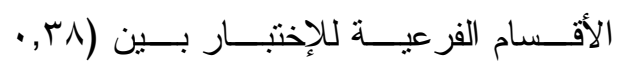

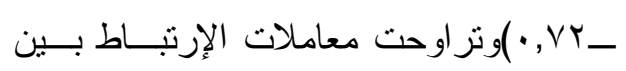

الأقسام الفرعية للإختبار و الدرجة الكلية بـين الإنين

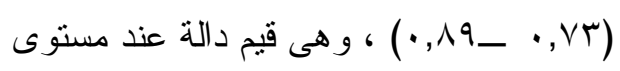

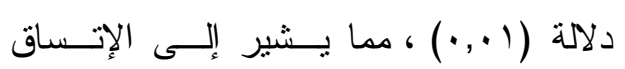

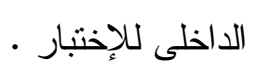

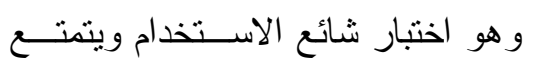

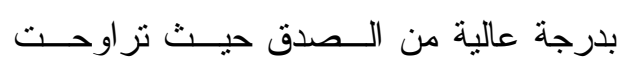

معاملات الــصدق التلازمــي بــين إختبــــار

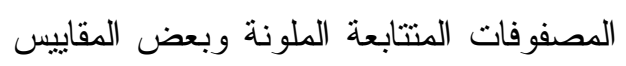

من جدول(Y) يتضح أن عدد أفراد العينــة

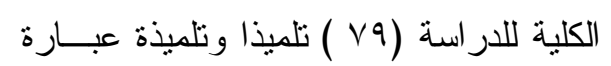

- عدد ( و ) ) تلميذا وتلميذة يمنلون عينة

ذوى صعوبات تعلم الرياضيات.

- عدد(• ع ) تلميذا وتلميذة يمنلون عينــة

\section{العاديين. \\ ج) ادوات البحث:}

إستخدمت الباحثة الأدوات التالية :

1 - إختبـر المصفوفات المتتابعة الملونـــة

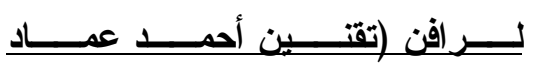

حسن، \& 1 . r):

أ ) الهُف من الإختبِار : تعد مصفوفات "

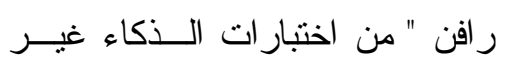

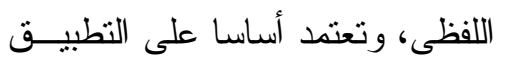


r- إختبار تثخيصى تقــويمى فـى مسـادة

الرياضبات (إعداد الباحثة )

أ)-الهُخف من الإختبار :

تشخيص نقاط القوة و الضعف بمــنهج

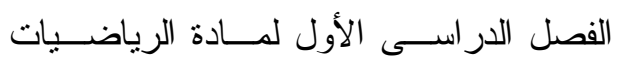

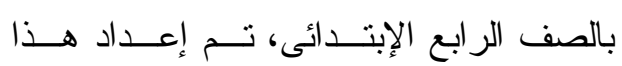

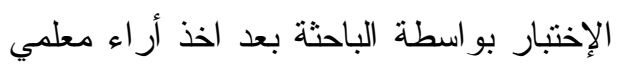
الرياضيات بالمدرستين حول مــدي مناسـبة الأسئلة للتلاميذ وللمنهج.

\section{ب) وصف الإختبار :}

يتكون الإختبار من جr فقرة مقـسمة

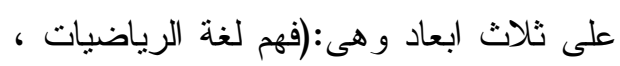

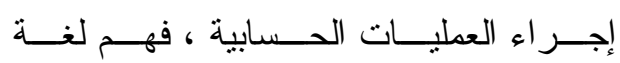

الرياضيات+ إجر اء العمليات الحسابية )

ج) الخصائص السبكومترية للإختبار :

$$
\text { اولا : الإتساق الداخلى : }
$$

تم حساب الإتساق الاخلى من خــلاد

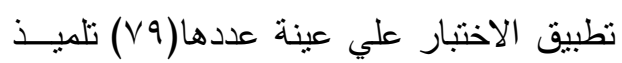

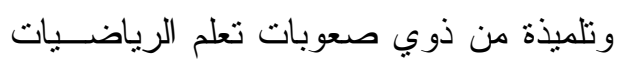

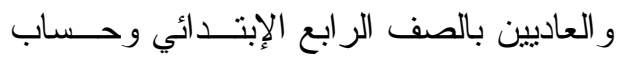

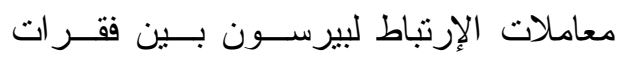

الإختبار و الارجة الكلية للإختبار ، وتز اوحست لإدبات

معاملات الإرتباط بين الفقرات وكل بعد مــا

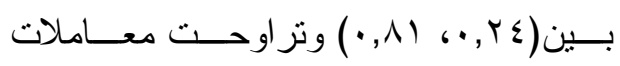

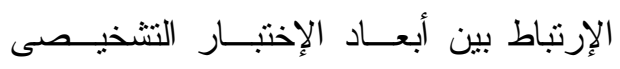

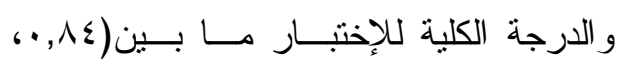

الفرعية لإختبار وكسلر للأطفال( المفردات، سلاسل الأعداد، رسوم المكعبات، الثفرة )

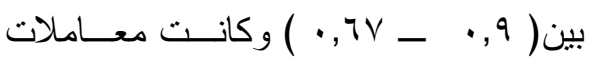
الثبات بطريقــة إعــادة تطبيــق الإختبــار

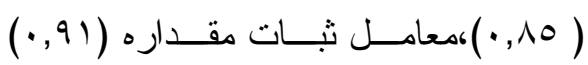
بطريقة التجزئة النصفية وهي معاملات دالة

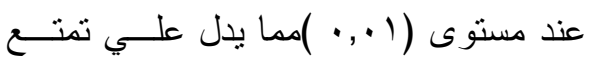
الاختبار بدرجة عالية من الثبات.

r-بطارية مقاييس التقــير التثخبـصبة لصعوبات التعلم النمائبة والأكاديمبــية

\section{(LDDRS)}

( فتحــى الزيــات ، 10 ـ ب)، حيــث تـــ إستخدام المقاييس التالية :

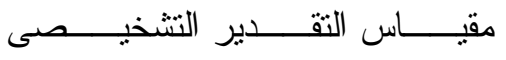

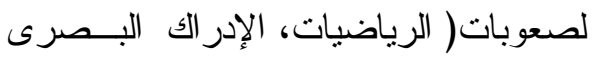

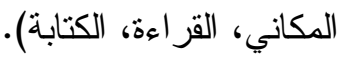

الهدف من هذه المقاييس: الكثف عن

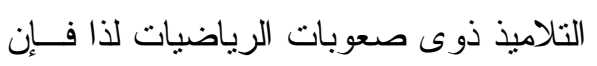

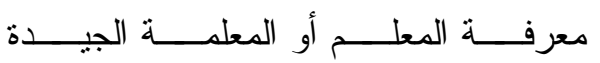

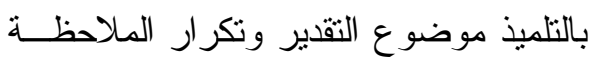

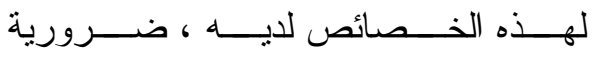

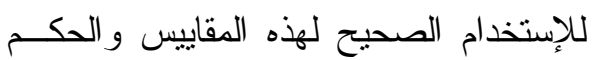
و التقدير الصادق من خلالها، وهى مقــاييس

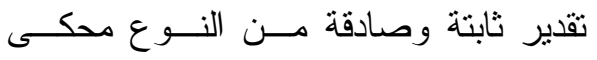

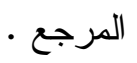


ب)(الصدق التمييزى (صــدق المجموعـات

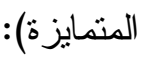

تم حساب صدق الاختبــار بأســلوب المجموعــات المتمــايزة بتطبيــق الاختبــار علي(q) تلميذ وتلميذة من ذوب صـــوعات

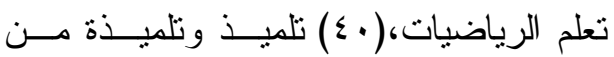
العاديين، مع ايجاد الفروق بـين منوســطات درجاتهم علي الاختبار و استخدام اختبار" ت " للمجموعات المستقلة لحساب الفـروق بــين متوسطات درجات المجموعتين علــى بنــود الاختبار حيث كانت قيم"ت" لبنــود الاختبـــار

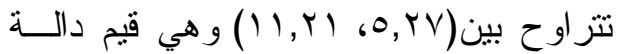

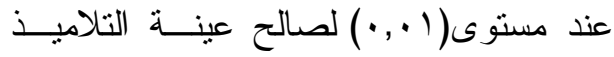
العاديين مما يسـثير إلــى صـــدق الاختبـــار باستخدام المجموعات المتمايزة، مما يشير إلى لي أن هذا الإختبار جاء مميز ا بين التلاميذ ذوي صعوبات تعلم الرياضيات و أقر انهم العـاديين من تلاميذ الصف الر ابع الابتدائي. ج) الصدق التلازمى : حيث تر اوحت معاملات الإرنباط بـين درجــات الإختبــار التشخيــصى و إختبـــار

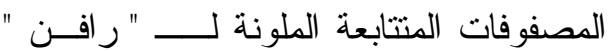
كمحك خارجى بين (10, · ، عـ, • ) وكانت

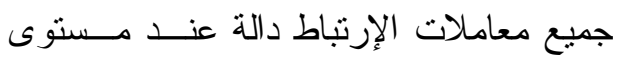
(1, (. ) ) ، مما يشير إلـى تمتــع الإختبـار

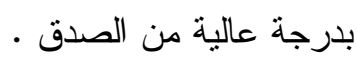

9V , · )، وكانت معاملات الإرنباط بين أبعاد الإختبار و الدرجة الكلية دالة عند مسستوى (1) للبنود كانت جميعها دالة عند مستوى دلالة

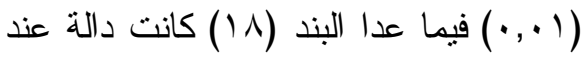

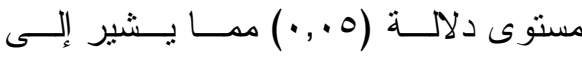

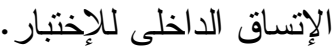
ثانيا : الصدق Validity :

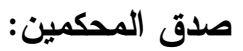
تم حساب صدق المحكمين حيث تم عرض المقياس في صورته المبدئية علا عددا من اســـاتذة علــم الــفـس التربــوي،

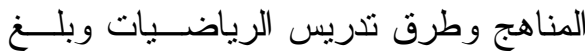
عددهم (1) من المحكمين وطلبت الباحثة منهم إبداء الر أي حول مدي ملائمة الاختبار لقياس ما وضع لقياسه، وحذف و إضافة مـــا يرونه مناسبا، تعـديل الــصباغة اللغويـــة

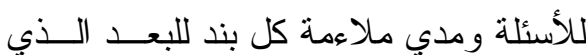

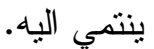
وتز اوحسـت نـسبة الإتهــاق بـين

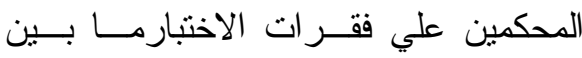

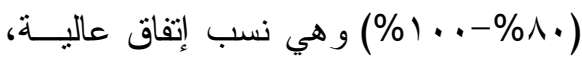
وبهذه الصورة فإنه يتمتع بدرجة معقولة من الصدق مما يجعله قابلا للنطبيق علي تلاميذ الصف الرابع من الحلقة الاولــي بـالتعليم

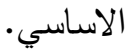




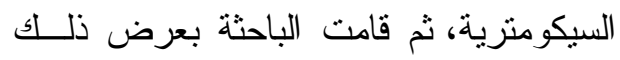

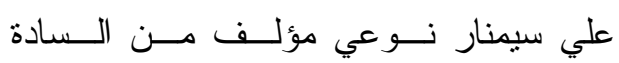
المشرفين علي الرسالة، وعدد مــن أســاتذة

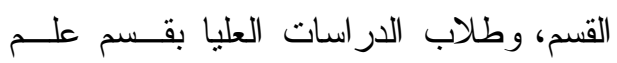

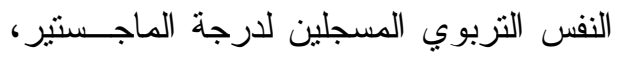
و الدكتور اة بموضو عات تعلق بالبطارية، حيث

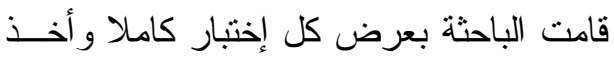

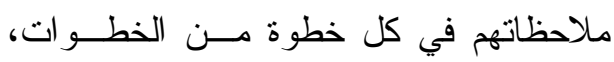

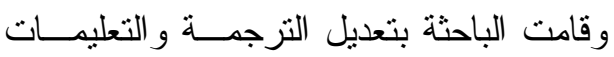
وكل منطلبات النطبيق وتسجيل الاســتجابات، ولنائ ثم قامت الباحثة بعرض التعديلات التــي تــــ إجر ائها في سيمنار نوعي اخـر و هـــا مــــا أعنبرته الباحثة بديلا لصدق المحكمين علـي

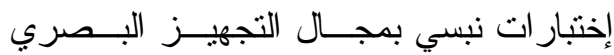
المكاني ببطارية (NEPSY-2).

اولا : إختبار بناء القوالب: البطان أ) الهُف من الإختبار : تقييم قدره التلميذ على تكوين بناء ثلاثى الابعاد مــن الــصور

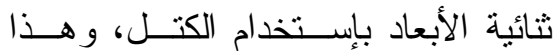
يتطلب دمج مهار ات الابصـار الفراغـي لئسي

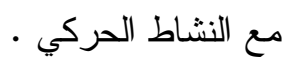
ب) وصــف الإختبـــار: يتكــــون الإختبــار من(9 (1)بند مرتبة من الأسهل للأصــعب الإئب

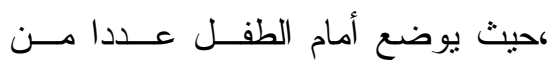
المكعبات ليستخدمها فى تكــوين البنــاء

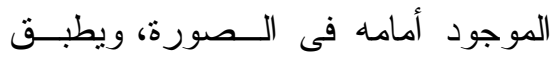

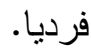

ثالثا: الثبات Reliability

قامت الباحثة بحساب ثبات الإختبــار بطريقة ألفا - كرونباك، حيث نم التحقق من بن بات الخات ثبات الاختبار باستخدام أسلوب ألفا كرونباخ

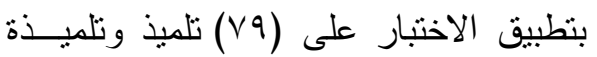

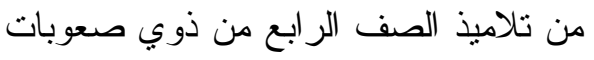

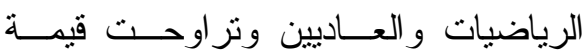
معاملات ثبات الفا كرونباخ ما بين (77, • ، ،

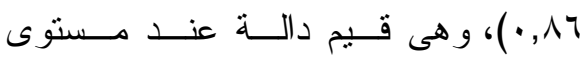
( ( ) , •)، و هذه القيم تشير إلى ثبات مرتفع للإختبار التشخيصى، وبذلك يعد الإختبــار ملائما لأغر اض البحث الحالي.

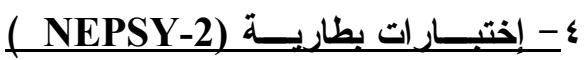
لمجال التجهيز البصري المكاني، اعداد كلا من:

Korkman, Kirk,

ويحتوى هــذا المجــال (Kemp,2007a) بالبطارية على(0) إختبار ات فرعية وهى:( إختبار بناء القو الب، إختبار إيجاد الطريـقـ،

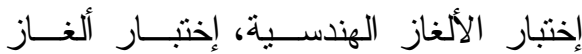

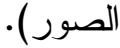

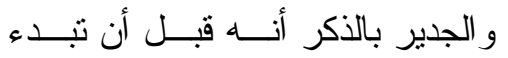
الباحثة في إستخدام إختبار ات مجال التجهيز البصري المكاني ببطارية نبسي-r قامــت الباحثة بتزجمتها من حيث تعليمات وطريقة

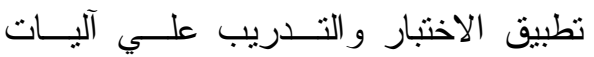

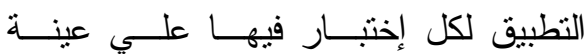

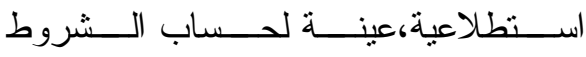


بالصورة أمامه بشرط أن يكون فـى الــزمن

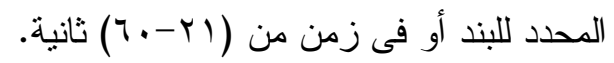

درجتان: وتعتبر هذه بمثابــة مكافــأة

للتلميذ الذى يجيب بشكل صحيح وفى زمسن ونئن

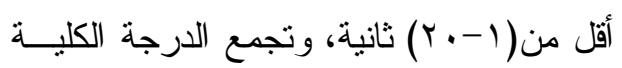

للبنود لتمنل درجة كل تلميذ على الإختبار .

هـ) الخصائص السبكومترية للإختبار :

اولا: الإنساق الداخلى:

تم حساب الإتساق الداخلى من خــلاد

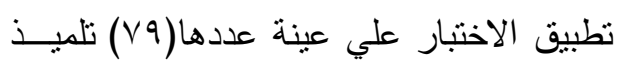

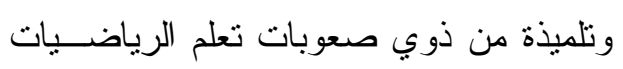

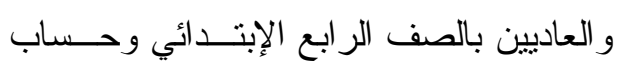

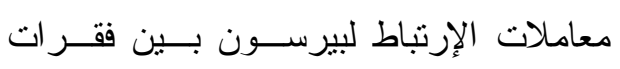

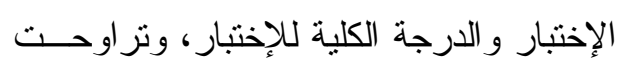

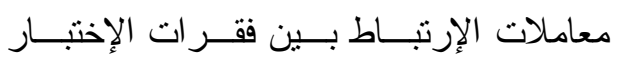

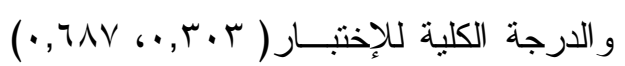

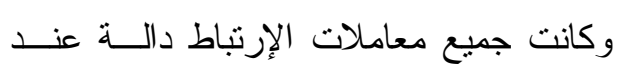

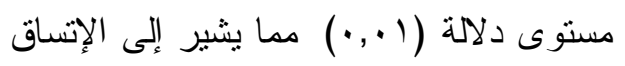

الداخلى للإختبار .

ثانيا: الصدق: الــصدق التمييـزى (صـــق

\section{المجموعات المتمايزة):}

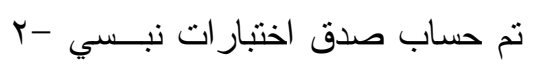

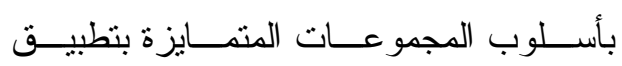
الاختبار علي (q) تلميذ وتلميذة مـن ذوبي صعوبات تعلم الرياضيات،( • ع) تلميذ وتلميذة من العاديين، مع ايجاد الفروق بين منوسطات

\section{ج) ت تعليمات تطبيق الإختبار :}

- العمر الزمنى المناسب لنطبيق الإختبار

من(س- 7 (1)عام بإختلاف نقطة البداية

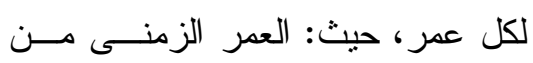

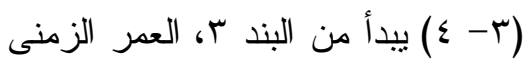

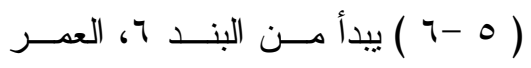

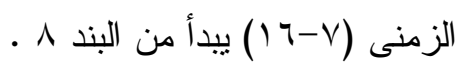

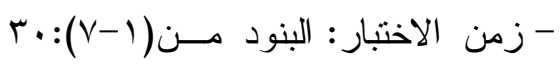

ثنانية لكل بند، و البنود من (1 - 9 (1) ):

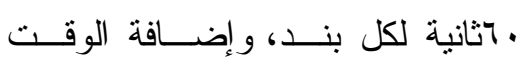

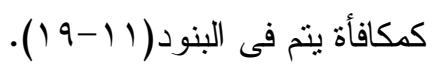

نقطة التوقف: فى حالة أن يعطى التلميذ

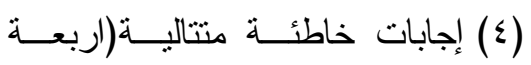

أصفار منتالية )

د) طريقة تصحيح الإختبار: بالنسبة للبنــود

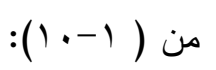

صفر: فى حالة عدم تكوين التلميــذ

البناء بالمكعبات بشكل ممانل لماهو موجود في لكون

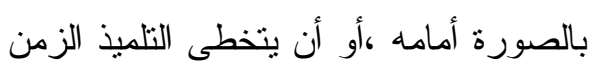
المحدد للبند.

درجة واحدة: فى حالة تكوين التلميذ

البناء بالمكعبات بشكل ممانل لماهو موجود

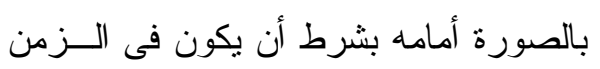
المحدد للبند أو فى زمن أقل. بالنسبة للبنود من (1)

درجة واحدة: فى حالة تكوين التلميذ

البناء بالمكعبات بشكل ممانل لماهو موجود 
و القدرة على التوجه الــسليم للوصـــول

للهدف من نقطة البداية .

ب) وصف الإختبار: يتكون الإختبـار مـن

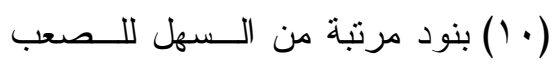

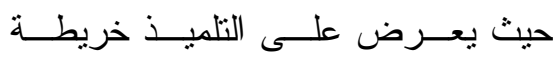

تخطيطية لمنزل مستهدف ويطلب منــــ

العثور على المنزل في خريطة أكبر ذات

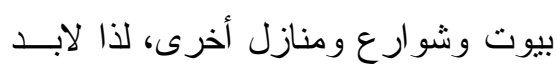

أن يكون لدى الثلميذ القدرة على إستخدام

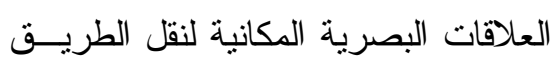

من الخريطة البسيطة الـى الخريطــة

الأكثر تعقيدا، ويطبق فرديا.

ج ) تعليمات تطبيق الإختبار:

- لعمر الزمنى المناسب لتطبيق الإختبــار

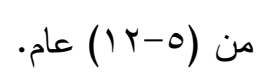

- نقطة التوقف: فى حالة أن يعطى التلميذ

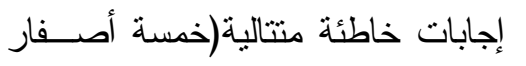

منتالية)

\section{د) طريقة تصحيح الإختبار: بالنـسبة للبنــود}

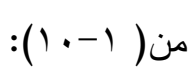

صـفر: فى حالة عدم قدرة التلميذ على

$$
\text { تحديد المنزل الصحيح. }
$$

درجة واحدة: فى حالة قـدرة التلميــذ

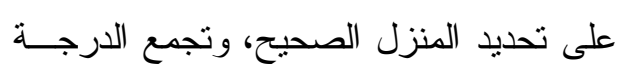

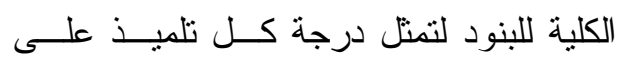

درجاتهم علي الاختبار و استخدام اختبار" ت

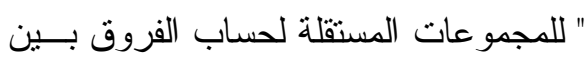

متوسطات درجات المجموعتين على بنــود

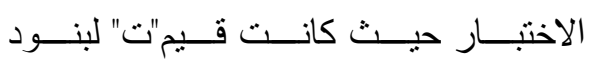

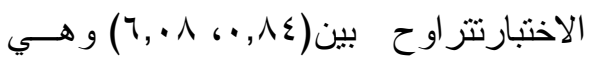
قيم دالة عند مستوى( ( , ·)، مما بدل علي وجود فروق ذات دلالة إحصائية بـين ذوي لئي صعوبات تعلم الرياضيات و أقر انهم العاديين

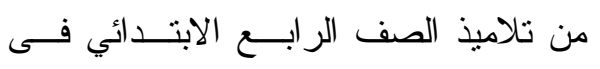
إختبار بناء القو الب لصالح التناميذ العاديين باستخدام طريقة المجموعات المتمايزة.

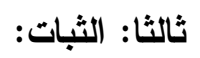

قامت الباحثة بحساب ثبات الإختبــار

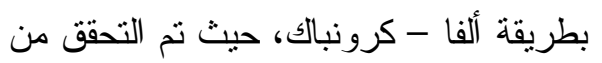
ثبات الاختبار باستخدام أسلوب ألفا كرونباك

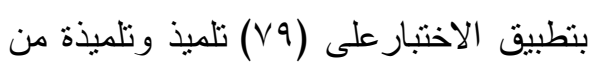

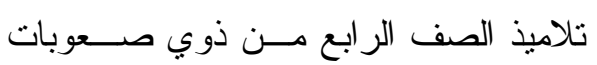

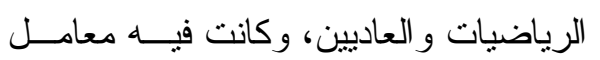

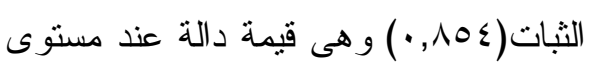
(1 +., ) وهذه القيمة نشير إلى ثبات مرتفع لإختبار بناء المكعبات ، وبذلك يعد الإختبار ملائما لأغر اض البحث الحالي. ثانيا : إختبار إيجاد الطريق : الطرائي

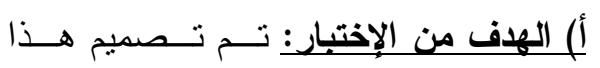

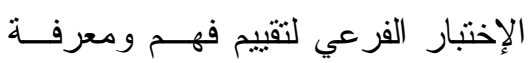
التلميذ للعلاقـــات البــصريه المكانيــة فئة 
يدل علي وجود فروق ذات دلالـــة إحــصائية بين ذوي صعوبات تعلم الرياضيات و أقر انهم العاديين من نالميذ الصف الر ابع الابتدائي فى لئي إختبار ايجاد الطريق لصالح التلاميذ العاديين باستخدام طريقة المجمو عات المتمايزة.

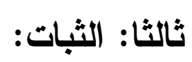

قامت الباحثة بحساب ثبات الإختبــار

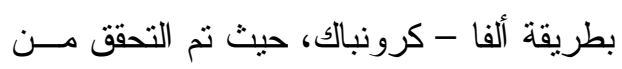
ثبات الاختبار باستخدام أسلوب ألفا كرونبــاك بتطبيق الاختبار على (V9) تلميذ وتلميذة مـن بـن

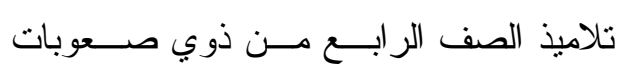

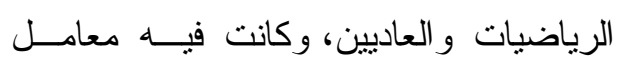

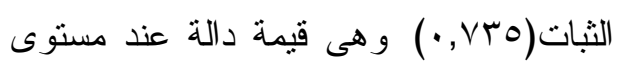

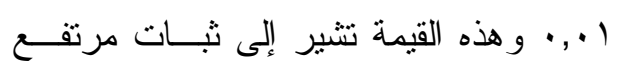
لإختبار إيجاد الطريق، وبذلك يعد الإختبــار ملائما لأغر اض البحث الحالي. ثالثا : إختبار الألغاز الهندسية : لاغئية

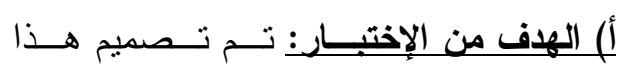

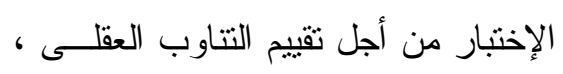

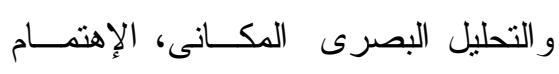
بالتفاصيل ، إدر الك الإتجاهات ، وجوانب الإنب الادر الك البصري المكاني .

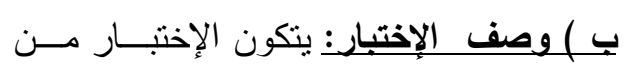

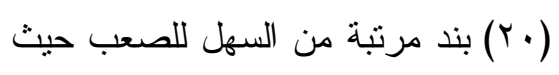

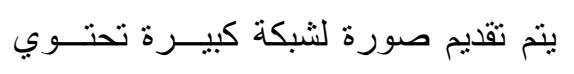

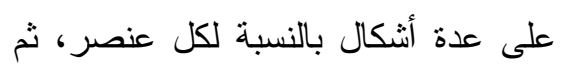

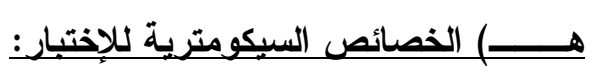
اولا : الإنساق الداخلى :

تم حساب الإتساق الداخلى من خلال تطبيق الاختبار علي عينة عددها(V9) تلميذ خون وتلميذة من ذوي صعوبات تعلم الرياضيات

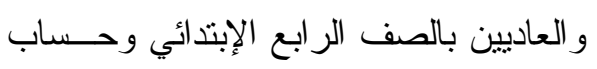

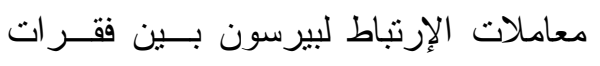

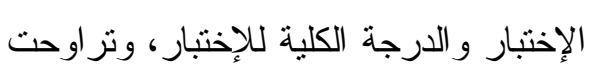
معاملات الإزتباط بــين فقــر ات الإختبـــار

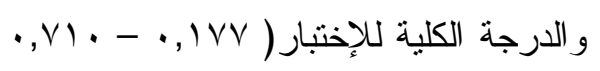

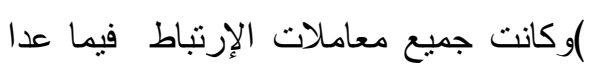
البند الأول دالة عند مستوى دلالـــة (1 ., •.) مما يشير إلى الإتساق الداخلى للإختبار

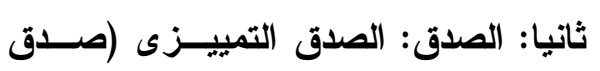

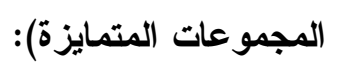
تم حساب صدق اختبار ات نبسي بأسلوب المجموعــات المتمــايزة بتطبيــق الاختبار علي (q) تلميذ وتلميذة من ذوي

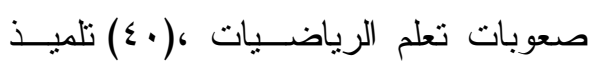
وتلميذة من العاديين، مع ايجاد الفروق بـين متوسطات درجاتهم علي الاختبار و استخدام

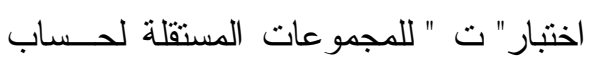
الفروق بين متوسطات درجات المجمو عتين على بنود الاختبار حيث كانت قيم"ت" لبنود

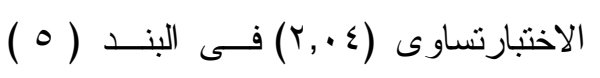

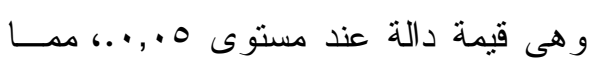


درجتــــان: إذا تـــم اعطــاء اجــابنتين

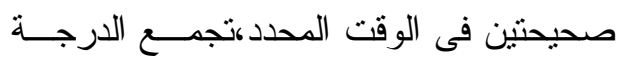

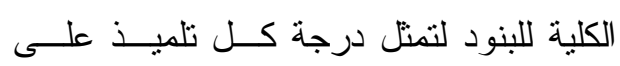

الإختبار • الإنه

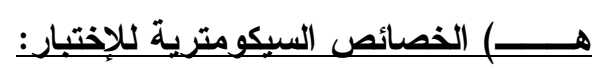

$$
\text { اولا : الإتساق الداخلى : }
$$

نم حساب الإتساق الداخلى من خــال

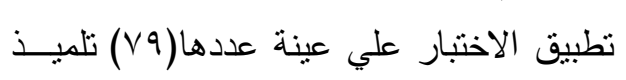

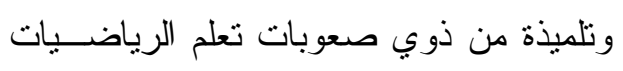

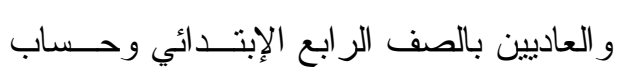

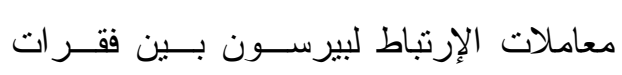

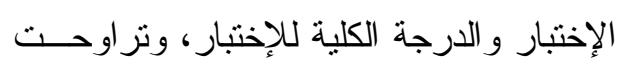
معاملات الإرتبــاط بــين فقـــــات الإختبــار

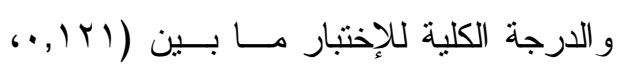

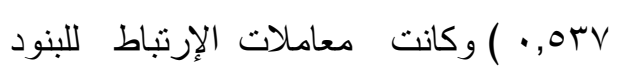

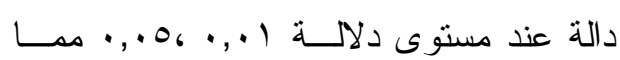
يشير إلى الإتساق الداخلى للإختبار .

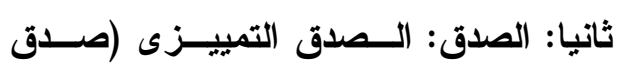
(المجموعات (لمتمايزة): تم حساب صدق اختبار ات نبسي -r بأسلوب

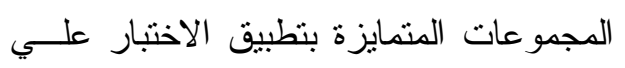

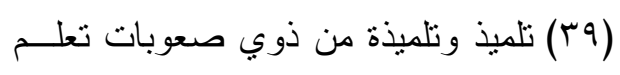

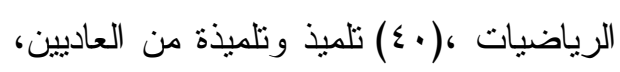
مع ايجاد الفروق بين متوســـات درجــاتهم

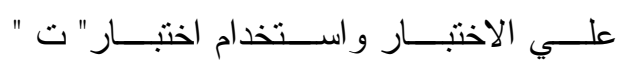
للمجموعات المستقلة لحساب الفـروق بــين الفين
يقوم التلميذ بتوصيل شــكلين خــارج

الثبكة بشكلين داخل الـشبكة بحيــث يكون الشكل داخل الثبكة ممانل لمــا

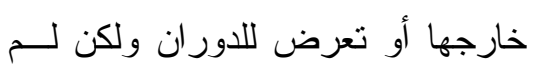
يحدث له إنقاب.

\section{ج) تعليمات تطبيق الإختبار:}

- لعمر الزمنى المناسب لتطبيق الإختبار

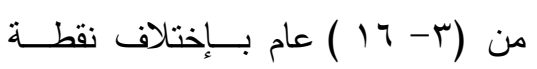

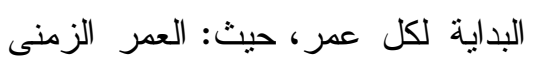
من (-0-1) مثال تدريبى (1 ) ثم البند

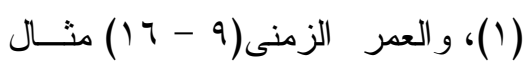

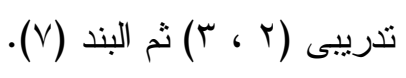

- زمن الاختبار : 0ـ ثانية لكل بند، حيث

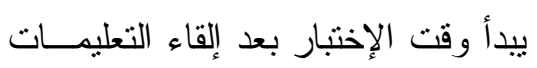

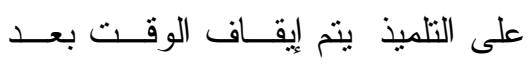
استجابة التلميذ. - لايوجد نقطة نوقف لهذا الإختبار فـى

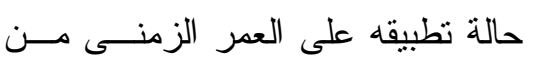

$$
\text { . (17-V) }
$$

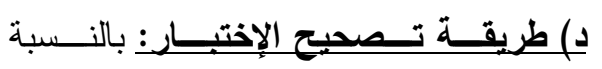
للعناصر من (1-1)

صفر: إذا لم تعطي الإجابة الصحيحة

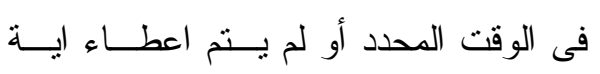

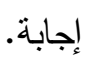

درجة واحدة: إذا كانت إجابة واحده صحيحة قد اعطيت فى الوقت المحدد. 
ب)وصف الإختبار: يتكون الإختبار من(Y)

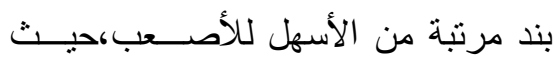

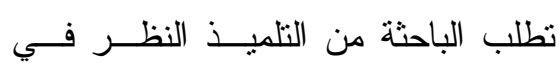

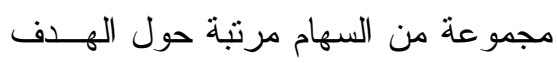

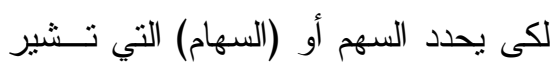
إلى قلب الهدف، ويطبق هـــا الإختبــار فرديا. ج ) تعليمات تطييق الإختبار: - العمر الزمنى المناسب لتطبيق الإختبـــار من (0- 17 ) ) عام بإختلاف نقطة البداية

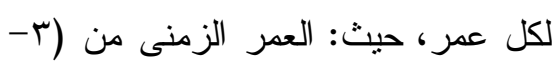

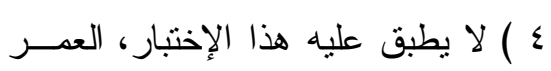
الزمنى من (0-1 ) يتم تطبيــق المثـــال

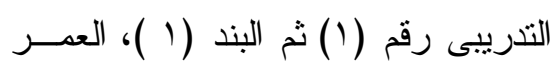
الزمنى من (9-9 (17 ) ينت نطبيق المنــال التدريبى رقم (r) ثم البند (0). - زمن الاختبار: هذا الإختبار غير محــد بزمن. - نقطة التوقف: فى حالة أن يعطى التلميذ (0) إجابات خاطئة متتالية(خمسة أصفار متتالية (0) د) طريقة تصحيح الإختبار: بالنسبة للعناصر $:(\varepsilon-1)$

صفر: إذا لم يعطي التلميذ أى إجابــة صحيحة.
متوسطات درجات المجموعنين على بنــود

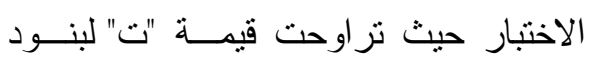

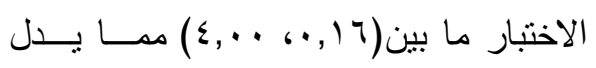
علي وجود فروق ذات دلالة إحصائية بـين

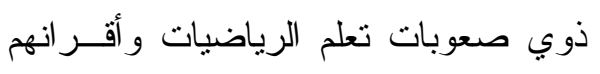
العاديين من تلاميذ الصف الر ابع الابتــدائي

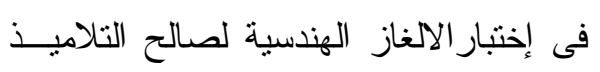

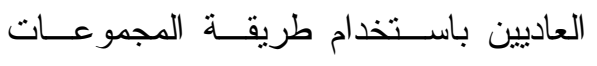
المتمايزة.

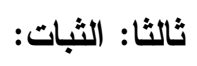
قامت الباحثة بحساب ثبات الإختبـــار

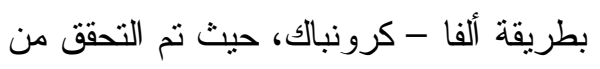
ثبات الاختبار باستخدام أسلوب ألفا كرونباك

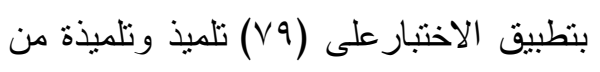

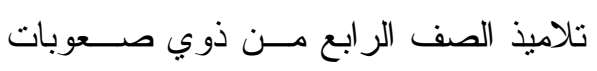

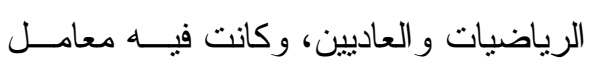

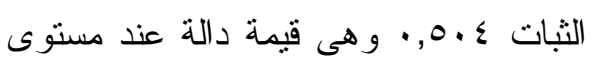

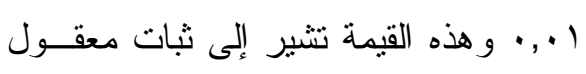

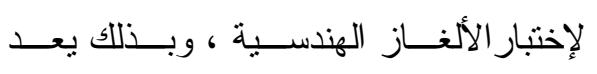
الإختبار ملائما لأغر اض البحث الحالي. لإني. رابعا: إختبار الأسيهز: أ) الههف من الإختبار: تقييم قدرة التلميــذ على الحكم على الاتجاه بدقــة وكـــللك التوجيه، زاويه توجه الخطوط، وكذلك

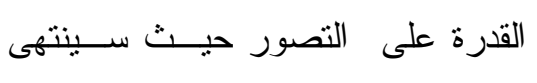
السهم. 
ثانيا: الصدق:الــصدق التميــزى (صـــق (المجموعات (لمتمايزة):

r- نم حساب صدق اختبار ات نبـسي

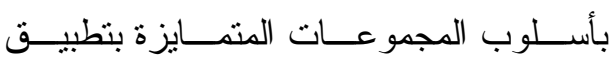

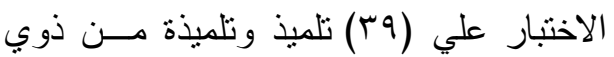

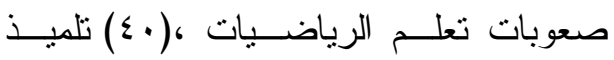
وتلميذة من العاديين، مع ايجاد الفروق بـين منوسطات درجاتهم علي الاختبار و اســتخدام

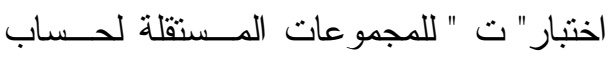
الفروق بين متوسطات درجات المجمـــوعتين

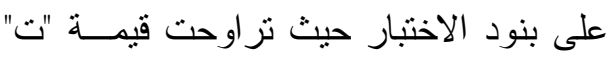

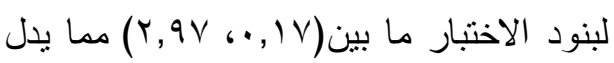
علي وجود فروق ذات دلالة إحـصائية بـين

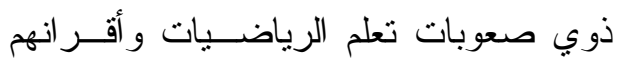
العاديين من تلاميذ الصف الرابع الابتدائي فى ولى لرئي إختبار الاســـهم لــصالح التلاميـــ العــاديين باستخدام طريقة المجموعات المتمايزة.

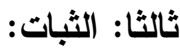

قامت الباحثة بحساب ثبات الإختبـار

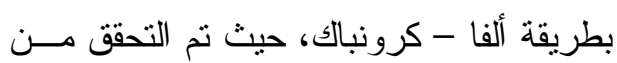

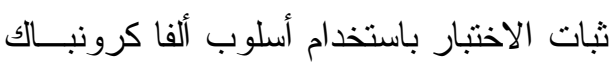
بتطبيق الاختبار على (V9) تلميذ وتلميذة مــن

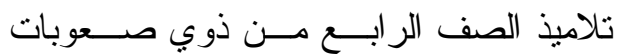

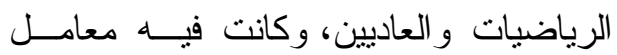
الثبات •عي, · و هى قيمة دالة عند مـستوى

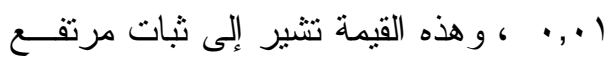

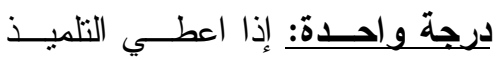
إجابة و احده صحيحة. أما بالنسبة للعناصر مـن (Y-0)

يزيد علي ماسبق ذكره بالنسبة للعناصر (1) ع انه:

درجتان: إذا اعطي التلميذ اجـابتين

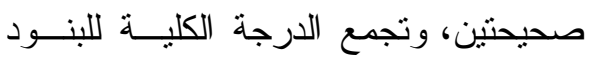
لتمنل درجة كل تلميذ على الإختبار .

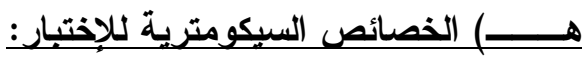
اولا : الإتساق الداخلى : تم حساب الإتـساق الــداخلى مـنـ

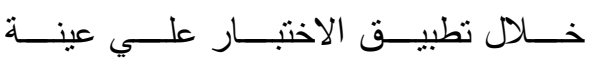

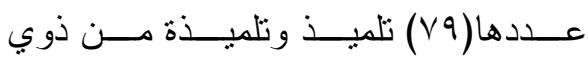

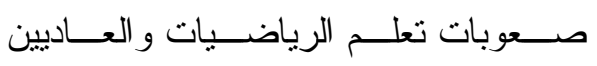
بالصف الر ابع الإبتدائي وحساب معساملات الإرتباط لبيرسون بــين فقــرات الإختبـــار

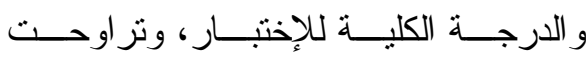

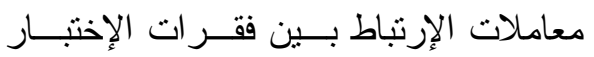

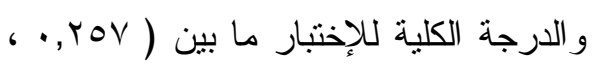

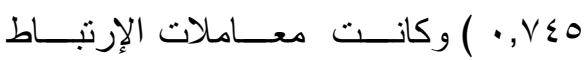

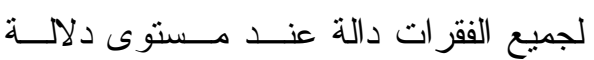
(1) معامل إرتباط هذه الفقرة دال عند مسستوى دلالة (0.,.•) مما يسشير إلــى الإتـساق

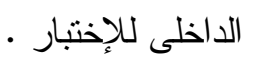


العمر الزمنى من (11 - 17 ) يتم تطبيق

$$
\text { المثال التدريبى ثم البند (^). }
$$

- نقطة التوقف: فى حالة أن يعطى التلميذ (7) إجابات خاطئة منتالية (ستة أصــفار

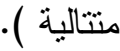

\section{د) طريقة تصحبح الإختبار:}

درجة واحدة: إذا تـــم تقـديم أربعـهـ

$$
\text { إجابات صحيحة فى الوقت المحدد. }
$$

صفر: إذا لم يتم تقديم أربعه إجابـات

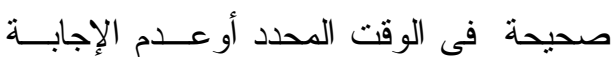

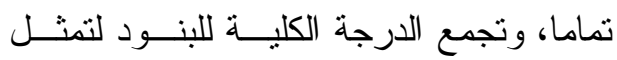

$$
\text { درجة كل تلميذ على الإختبار . }
$$

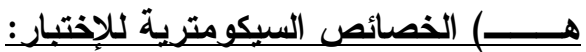

$$
\text { اولا : الإتساق الداخلى: }
$$

تم حساب الإتساق الداخلى من خــلدل

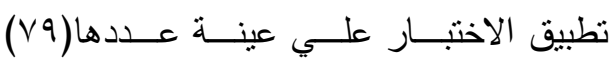

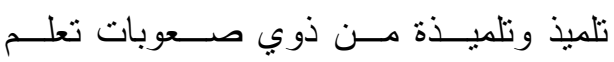
الرياضيات و العاديين بالصف الر ابع الإبتدائي

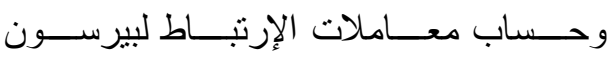
بين فقرات الإختبار و الدرجة الكلية للإختبار ،

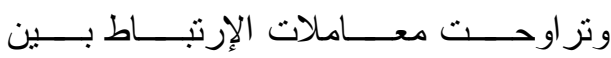

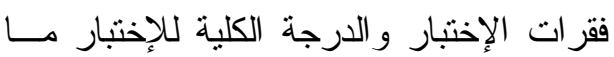

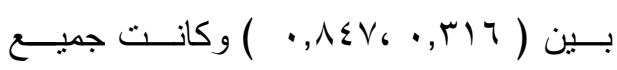

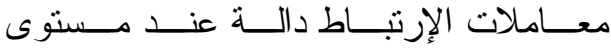

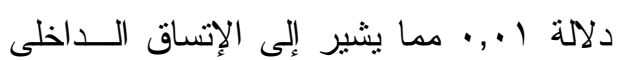

$$
\text { ل للإختبار - دلاله }
$$

لإختبار الأسهر ، وبذلك يعد الإختبار ملائما

$$
\text { لأغر اض البحث الحالي. }
$$

خامسا : إختبار ألغاز الصور:

أ) الهـف مــن الإختبــار: تقيــيم التمييـز

البصري، المسح البصري، و التكامــل

البصرى فضلا عن القدرة على تفكيــاك لكري،

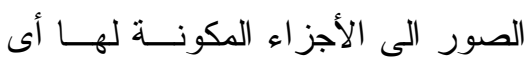

إدر الك علاقة الجزء بالكل.

ب ) وصف الإختبار: يتكون هذا الإختبار

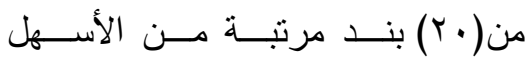
للأصعب، حيث ينم تقديم صورة كبيرة

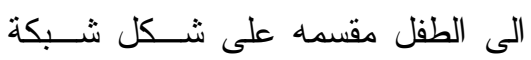
مقسمة الى أربع صور صغيرة مأخوذة

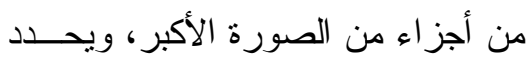
الطفل الموقع على الثبكة على الصورة

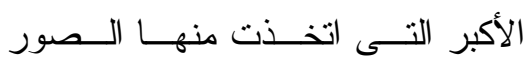
الصغيرة، ويطبق هذا الإختبار فرديا. ج ) تعليمات تطيق الإختبار: - العمر الزمنى المناسب لتطبيق الإختبار

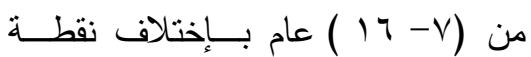
البداية لكل عمر، حيث: العمر الزمنى

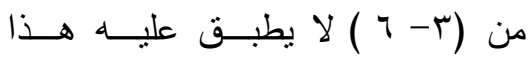

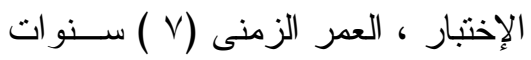

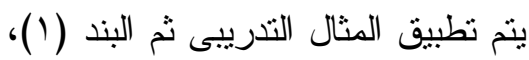

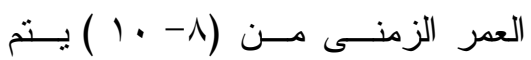
تطبيق المثال التدريبى ثـــم البنــــ (0)، 


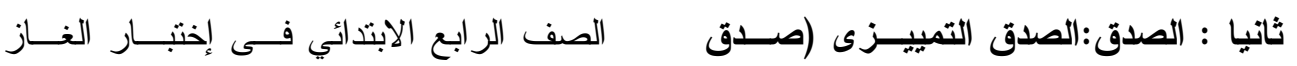

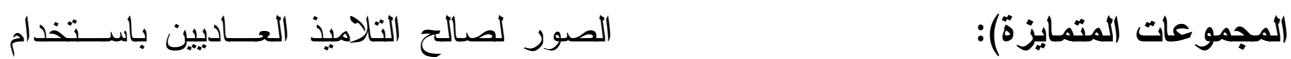

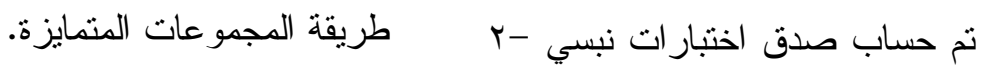

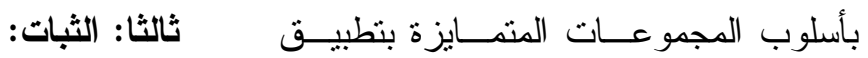

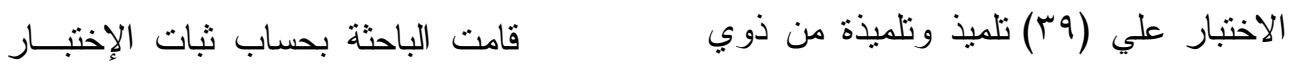

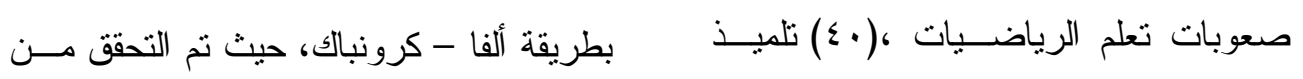

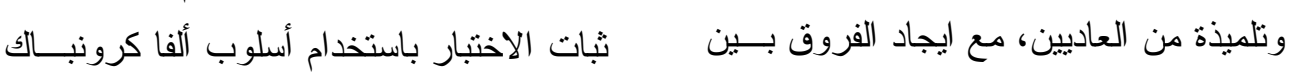

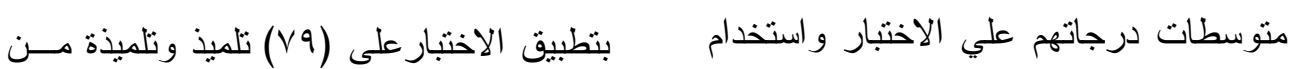

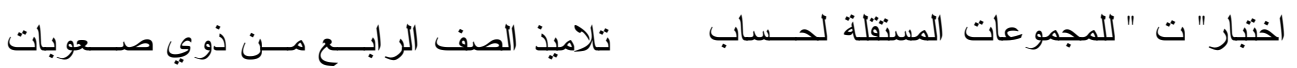

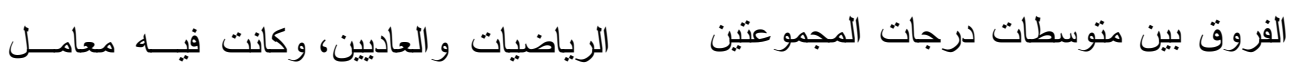

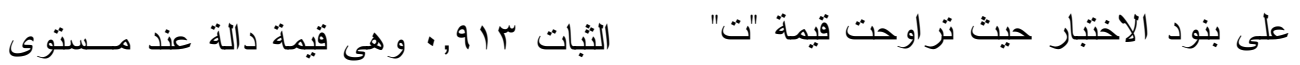

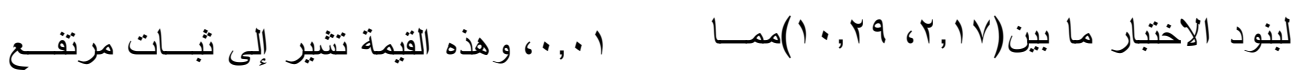

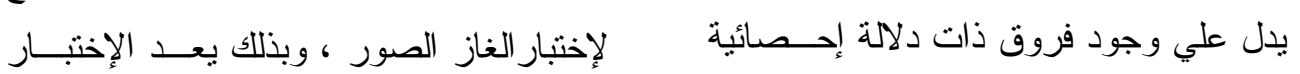

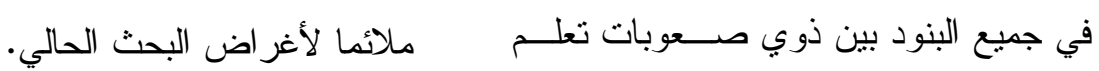

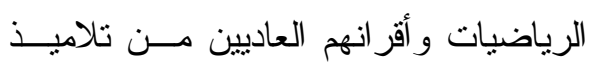


خطوات البحث: وللتحقى من فروض البحث ، قامت الباحثة بإجر اء الخطوات التالية:

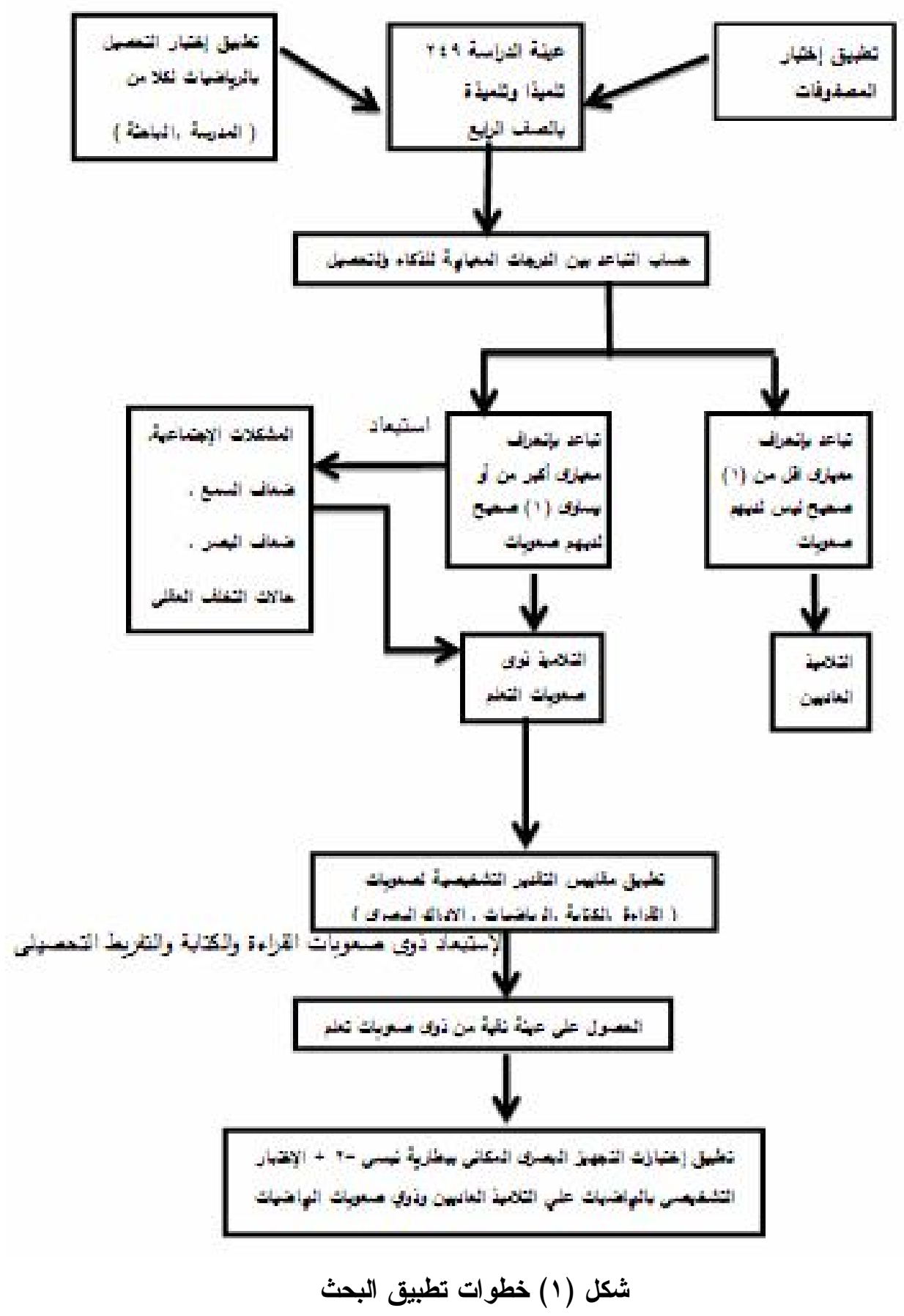




\section{نتائج الدراسة مناقشتها وتفسيرها:}

وللتحقق من نتيجة هذا الفــرض تــم

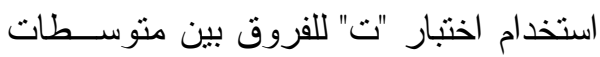

درجات المجموعات المستقلة للصف الر ابع، وأسفر ذلك عن بيانات الجدول التالي:
القرض الأول: بنص الفــرض الأول

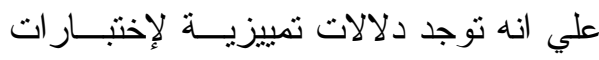

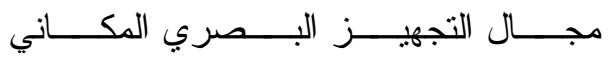
ببطارية(NEPSY-2)لاي ذوي صــوبات

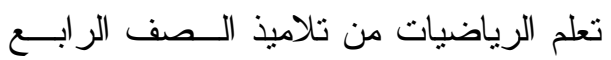

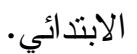

المتوسطات والاتحر افات المعيارية وقيمة "ت" ومستوى دلالتها للفروق بين عينة

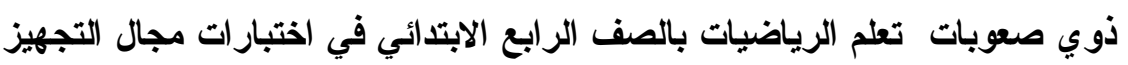

\begin{tabular}{|c|c|c|c|c|c|c|}
\hline \multirow[b]{2}{*}{ الدلالة } & \multirow[b]{2}{*}{ قيمة ت } & \multicolumn{2}{|c|}{ 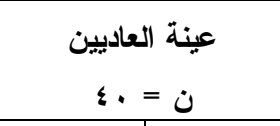 } & \multicolumn{2}{|c|}{ 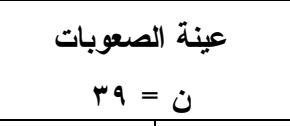 } & \multirow{2}{*}{ الإختبار } \\
\hline & & الإحعراف & المتوسط & الإحعراف & المتوسط & \\
\hline غير دالة & $\cdot, \leqslant 9$ & $r, \varepsilon$. & 0,1 & r,or & $\varepsilon, \wedge r$ & ايجاد الطريق \\
\hline. .1 & $r, r q$ & $r, \cdot \varepsilon$ & $r V, r r$ & $v, \cdot r$ & $r \leq, \varepsilon r$ & الأسهر \\
\hline. .1 & $\varepsilon, \ldots$ & rr, & $r V, r Y$ & $r, 1 \leq$ & $r \leq, r r$ & الألغاز الهندسية \\
\hline. .1 & $7, .1$ & r,Ar & $1 \varepsilon, T V$ & $r, \wedge q$ & $1, ., 0$ & المكعبات \\
\hline. .1 & $1, ., 19$ & $r, \cdot r$ & Ir,IV & $r, 97$ & $\varepsilon, .0$ & الصور \\
\hline
\end{tabular}

الهندسية ، و إختبــار المكعبــات ، و إختبــار

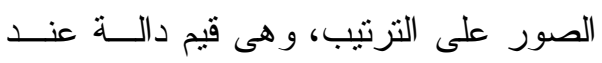

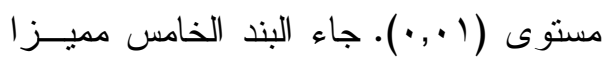
باختبار ايجاد الطريق.

كيثير ذلك إلى قدرة اختبار ات مجال التجهيز البصري المكاني ببطارية-NEPSY

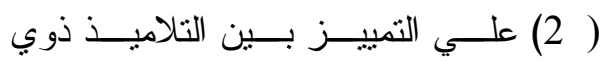

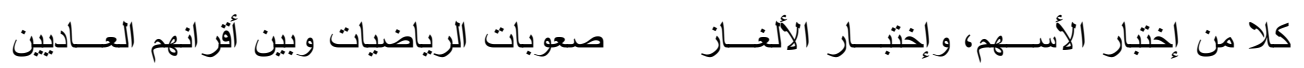

يتضح من جدول(r) أنه: نوجد فروق ذات دلالة إحصائية بين ذوي صعوبات تعلم

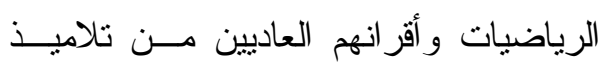
الصف الرابع الابتدائي فى اربعة إختبــارات التئن

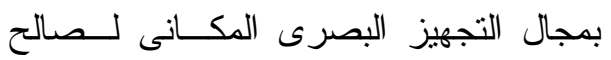

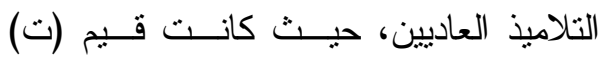

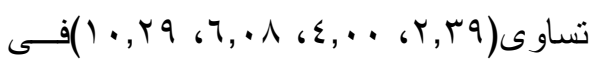


مميز ا بـين ذوي صـــوبات تعلــم

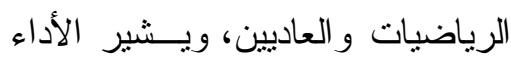

المنخفض علي هذا الإختبار علــي ان ونيان

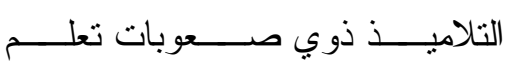

الرياضـــات يعــانون عــددا مـــن الصعوبات منل : لرياض

- صعوبات بصرية مكانية فى الحكـم

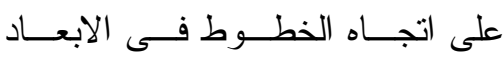

الثنائية، صعوبة فــى الحفــاظ علــى الهى

الصور الذهنية في الذاكرة العاملة.

-صعوبة التصور للعلاقات المكانية في

الحكم على الاتجاه بدقة؛ وفي تقــدير

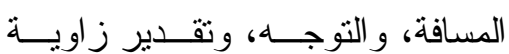

الخطوط.

- وترى الباحثة أن مثل هذه الخصائص

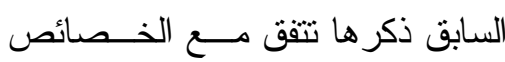

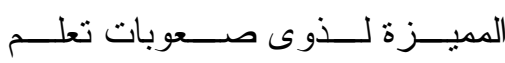
الرياضيات، ومن ثم فهــذا الإختبـــار

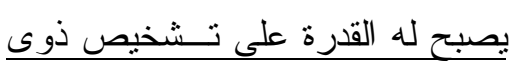
صعوبات تعلم الرياضيات.

ب) بالنسبة لاختبار الألغاز الهندسـية: جاءت بعض بنــود هــــا الإختبـــار

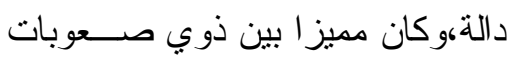

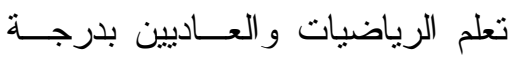
معقولة، ويشير الأداء المنخفض علي لئي هذا الإختبار علي ان التلاميــذ ذوي لئني
من تلاميذ الصف الر ابع الابتدائي، ويتـضح

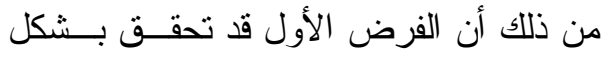

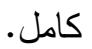
ويمكن تفسير هذه النتيجة في ضوء: 1- ان الاختبار ات الفرعية المت ضمنة فـي مجال المعالجـــة البــصرية المكانيـــة في NEPSY-II وهي الأســـه، بنــاء المكعبات، والألغاز الهندســية، وألغـــاز

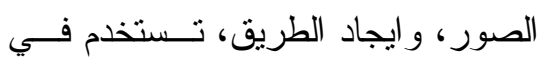
تشخيص وتقييم صعوبات القدرة علـي وليجي الحكم على وجهة الخط ، إعـادة بنــاء

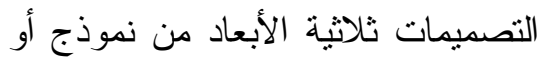

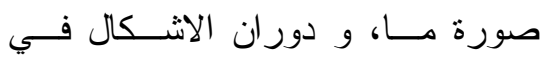
الفراغ، تفكيك صورة ما إلــي أجــز اء صغيرة، و التعـرف علـي العلاةــات

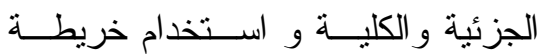

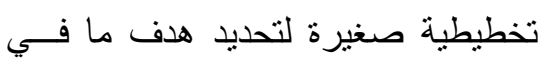
خريطة تخطيطية كبيرة. r- لذا تري الباحثة أن التلاميذ الذين يعانون

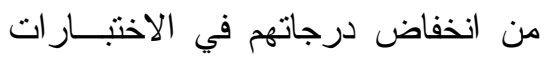

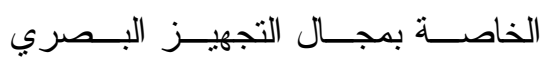

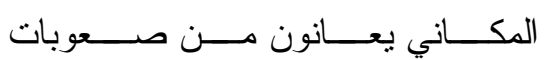
بالرياضيات، ولذلك فإنها تصلح للتمييز

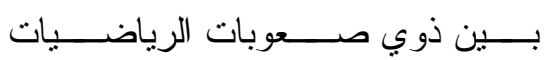
و العاديين.

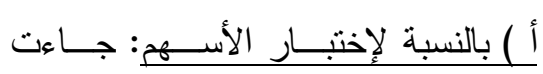
بعض بنود هذا الإختبار دالة، وكــان 
- القدرة على تحويل أو نزجمة او انتاج

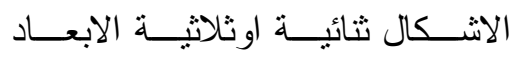
باستخدام الكتل لنسخ نماذج أو بنـــاء

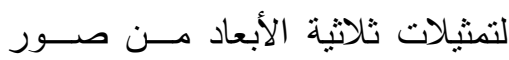
ثنائية الأبعاد.

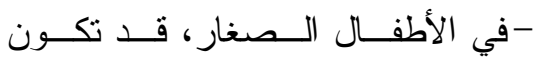
المشكلة الرئيسية فى صعوبات الرسم،

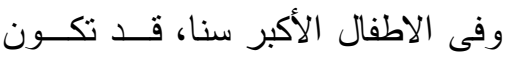

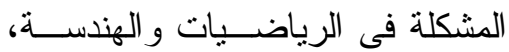

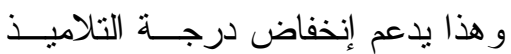

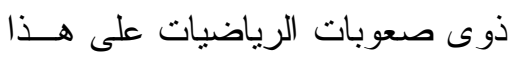

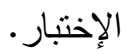

-وترى الباحثة أن مثل هذه الخصائص

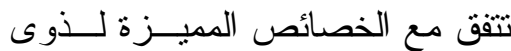
صعوبات تعلم الرياضيات ،وتـــؤدى بدورها إلى مشاكل فى الرياضــيات و الهندسة ومن ثم فهذا الإختبار يصبح

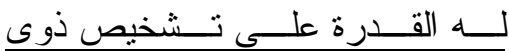
صعوبات تعلم الرياضيات. دـ ) بالنسبة لإختبــار ألغــاز الــصور:

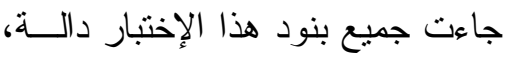

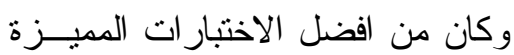
بين ذوي صعوبات تعلم الرياضـــات

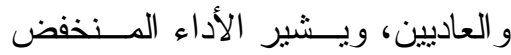

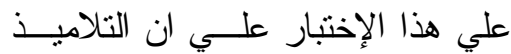
ذوي صعوبات نعلم الرياضيات لديهم صعوبات في:
صعوبات تعلــــم الرياضــيات لــديهم

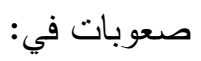
- القدرة على تحليل ومقارنه الجوانــب الهندسية من الأشكال بحيــث بكــون الشكل قد تعرض للاوران فى الفراغ ولكن لم يحدث له انقلاب، وذلك مـن اجل مقارنتها بالثكل الهادف و ادر الك الاتجاهات، القــدرة علـــى التــصور و التحليل البصري المكاني.

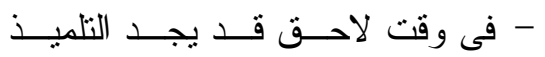
صعوبة في عمليه المعالجة الرياضية التي تعتبر أكثر تعقيدا بالنسبه للهندسة وحساب المنلثات و التفاضل و التكامل.

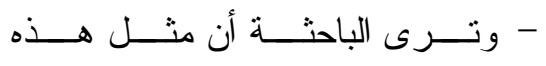
الخصائص تلفــق مــع الخــصائص

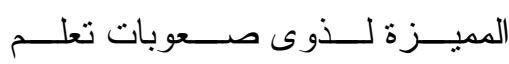
الرياضيات، ومن ثم فهــذا الإختبــــار

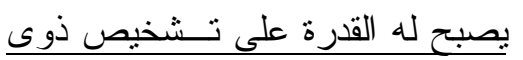
صعوبات تعلم الرياضيات.

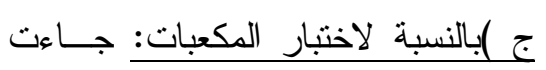
معظم بنود هذا الإختبار دالة،وكـــان من أفضل الاختبار ات المميـزة بـــين

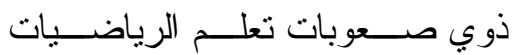

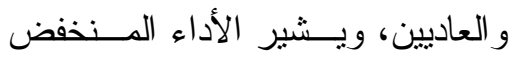

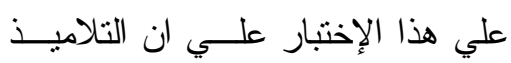
ذوي صعوبات نعلم الرياضيات لديهم

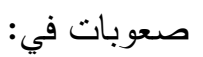




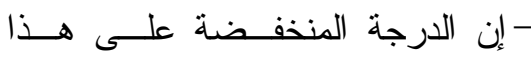

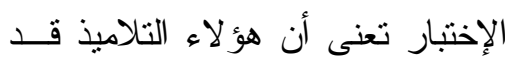

يظهرون صعوبات بــصرية مكانيــة

ولديهم مهار ات تخطيطية ضـــعيفة و

يعانون من صعوبات و اضحة في فهم

العلاقات المكانية (على سبيل المثنال،

الارتباك بين اليمين و اليسار ، مــشاكل

$$
\text { اتباع الخطو ات). }
$$

- ان الأداء الضعيف على هذا الاختبار يمكن أن يكون راجعا إلى صعوبة في تقدير المسافة من نقطة الانطلاق إلى النقطة المستهدفة، حيث ان التلميذ قد

$$
\text { يخلط اليسار مع اليمين. }
$$

- قد يجد بعض التلامبذ صعوبة فـي

تفسير الرسوم البيانية في أي مجال ) مما يدل على إرتباط بين هذا الإختبار

مع صعوبات تعلم الرياضيات ) .

وترى الباحثنة أن منل هذه الخصائص

السابق ذكرها نتفق مع الخصائص المميـزة

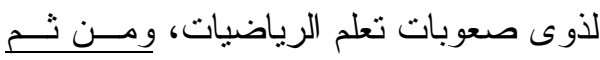

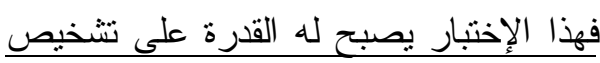
ذوى صعوبات تعلم الرياضبات .

ونزي الباحثة: أن وجود فــروق ذات

دلالة إحصائية بين التلامبذ العـاديين وذوي

صعوبات تعلم الرياضيات فــى اختبـــار ات

بطارية نبسي-r لصالح التلاميذ العاديين قد يكون راجعا إلى أن الأداء الجيد على هــذه
- القدرة على الإدر الك البصري و التمييز البصري، المسح البصري، فضلا عن القدرة علــى تفكيـــ الــصور إلــى الأجز اء المكونة لها، وتحديد التفاصبل المرئية البــارزة و إدراء الك علاقـات الجزء بالكل، وما سبق يفتقر وجــوده عند ذوى صعوبات تعلم الرياضيات. -وتزى الباحثة أن مثل هذه الخصائص السـابق ذكر ها تتفق مــع الخــصائص

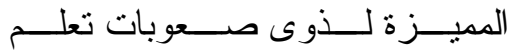

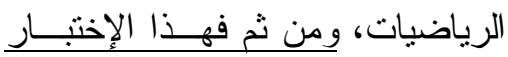
يصبح له القدرة على تـشخيص ذوى صعوبات تعلم الرياضيات.

هـ ) بالنسبة لاختبار إيجاد الطريـق

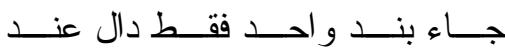
مستوي(0., +•)، وكان مميـزا بـين ذوي صــــوبات تعلـــم الرياضـــيات و العاديين بدرجة ضـــيفة، الجــدير بالذكر أنه على الرغم مــن أن هــذا الإختبار لم يميز بــشكل كبيــر بـين

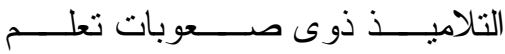
الرياضيات و العاديين، إلا أن هنــاك بعض التلاميذ ذوي صعوبات الـتعلم تز اوحت درجاتهم فى هذا الإختبــار من(1- r ) درجات فقط، وقد يرجع ذلك إلى : 
توصيات البحث:

في ضوء نتائج البحث و التي أثنــارت

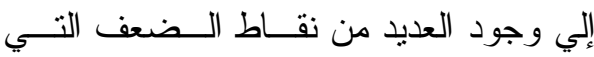

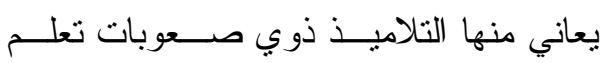

الرياضيات بمنهج الصف الر ابع من المرحلة الإبندائية، ووجود فروق ذات دلالة إحصائية

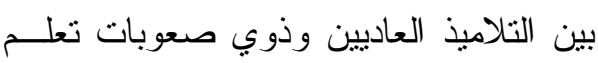

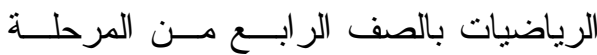

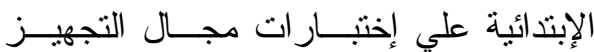

NEPSY- 2 البصري المكاني ببطاريسـة

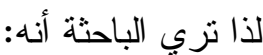

1 - ضرورة إستخدام المهتمـين بمجــال

صـــوبات الــتعلم عامــة، ومجـــال

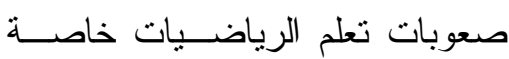

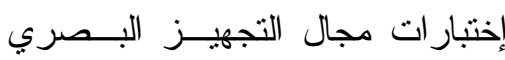

NEPSY- 2 المكاني ببطارية

تتخيص صعوبات نعلم الرياضيات.

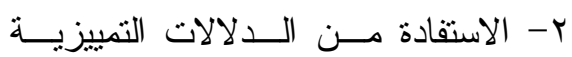

لاختبارات مجال التجهيـز البــصري

NEPSY- 2 المكاني ببطارية

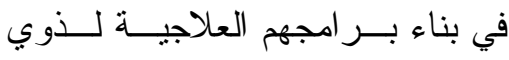
صعوبات تعلم الرياضيات.

r- علي المهتمين بالمجال الأخذ بالإعتبار

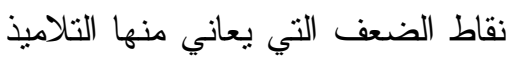
ذوي صعوبات تعلم الرياضيات بمنهج

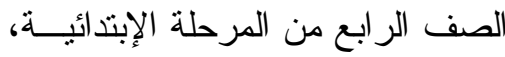
و البحث عن أساليب العلاج المناســبة الإنتية لهذه النقاط.
الإختبار ات يتطلب تو افر بعض الخــصائص

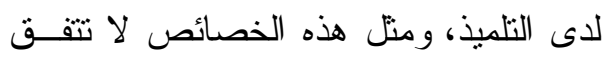
مع الخصائص المميزة لذوى صعوبات نعلم الرياضيات، ومن ثم جاءت هذه الإختبار ات

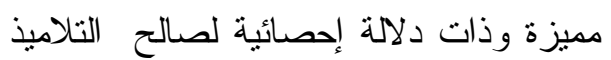

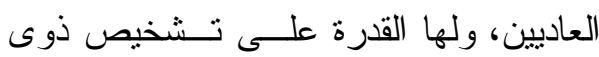
صعوبات تعلم الرياضيات .

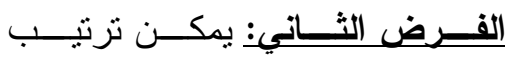

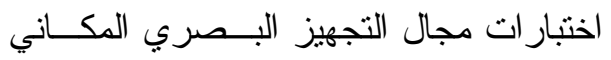

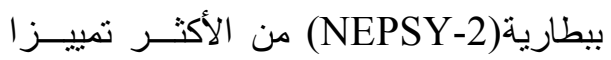

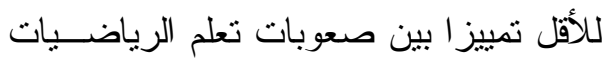
و العاديين.

استخدمت الباحثة مؤشر عدد البنــود التمييز بين ذوي صعوبات تعلم الرياضــيات وبين العاديين في تحديد الاختبار ات الأكثر لتربير تمييز ا والأقل تمييز ا، وأسفر ذلك عن فين التين

- اختبار الغاز الصور : جميع البنود مميزة و المجموع الكلي.

- اختبار بناء المكعبات:احدي عشر بنـــا

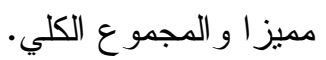

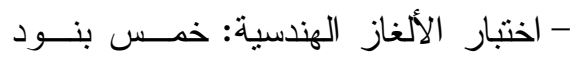

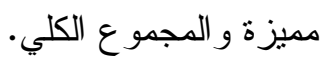

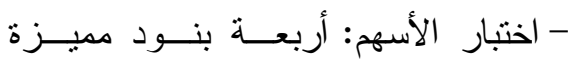
و المجموع الكلي. - اختبار إيجاد الطريق: بند واحــــ فقــ مميز البند (0). 
م (طץ). عمـــان. دار المــسيرة للنــشر و التوزيع و الطباعة.

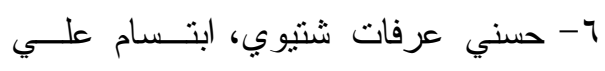

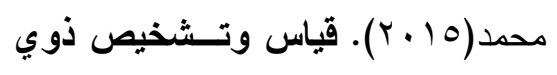

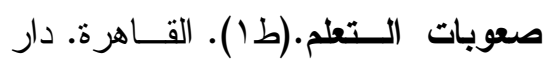
الزهر اء للنشر و التوزيع.

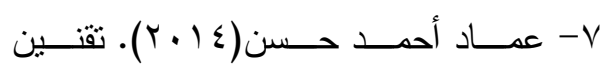

أختبار ات المصفوفات المتتابعة الملونـــة

لر افن. القاهرة. مكتبة الانجلو المصرية.

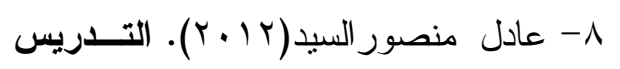

العلاجي للتلاميذ ذوي صعوبات التعلم.

المنصورة. دار الأصدقاء للطباعة.

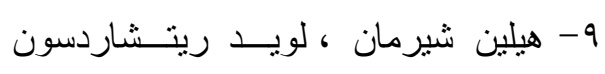

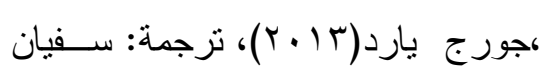

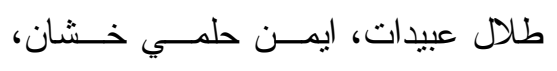

تدريس المتعلمين ذوى صعوبات التعلم

فى الرياضيات تلخل منظومي وعلاجي.

الرياض. ادارة النشر العلمي و المطابع.

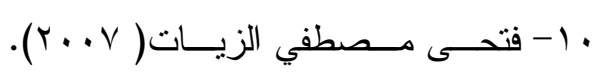

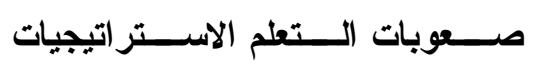

التدريسية و المداخل العلاجية. ( ط ا). القاهرة. دار النشر للجامعات.

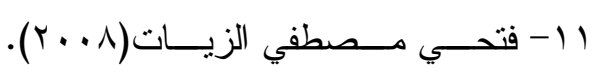

قضايا معاصرة في صعوبات الــتعلم. (ط ) ( القاهرة. دار النشر للجامعات.

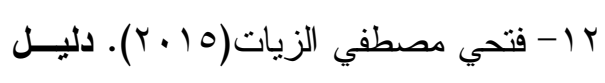
بطارية مقاييس التقدير التشخيـصية
المراجع:

1- أحمد عفت مــصطفي قرشـــ، هــشام

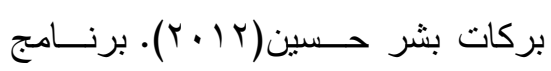

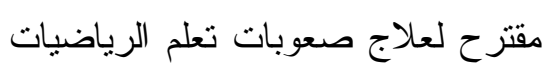

لدي تلاميذ المرحلة المتوسطة في ضوح

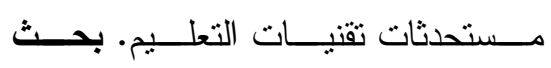

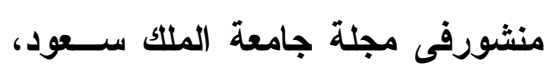

مجلا(؟ Y)،العلوم التربوية و والدراسات

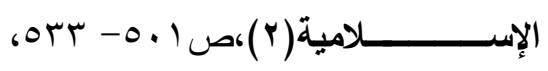

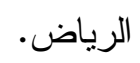

r- أحمد أحمــد عــو اد (ب9 (199). فاعليــة

برنامج تدريبى لعلاج بعض صـــوبات

التعلم لدى نلاميذ المرحلـــة الإبتدائيـــة.

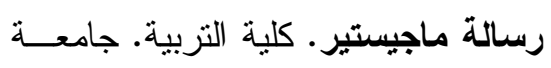

بنها.

r- أســـامة محمـــد البطانيــة،همالك أحمــد

الرشدان، عبيد عبد الكريم السبايله، عبد

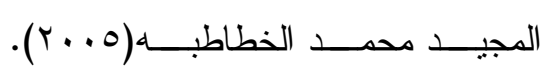

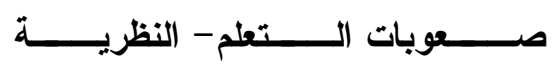

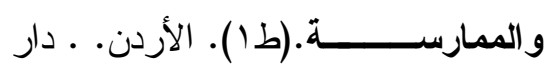

المسيرة للنشر و التوزيع و الطباعة.

ع- السيد أحمــد محمــود صــقر (10 • r).

صـــوبات الــتـعلم(الأســس النظريـــة

و التشخيصية و العلاجية). (ط ) ).القاهرة.

مكتبة الأنجلو المصرية.

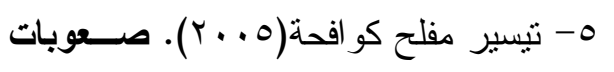

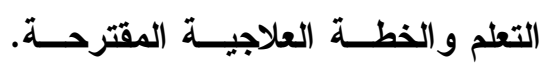


16- Geary, D. C., Hoard, M. K., Byrd0Craven, J., Nugent, L., \& Numtee, C.(2007). Cognitive mechanisms underlying achievement deficits in children with mathematical learning disability. Child development, 78(4), 13431359.

17- Korkman, M., Kirk, U., \& Kemp, S. (2007a). NEPSY-II:

Clinical and interpretive manual. San Antonio, TX: The Psychological Corporation.

18- Korkman, M., Kirk, U., \& Kemp, S. (2007b). NEPSY-II: A developmental neuropsychological assessment. San Antonio, TX: The Psychological Corporation.

19- Hegarty, M., \& Kozhevnikov, M. (1999). Types of visualspatial representations and mathematical problem

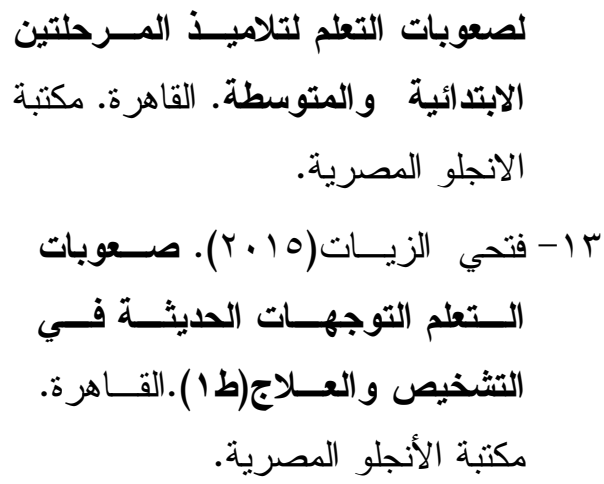

14- Assel, M. A., Landry, S. H., Swank, P., Smith, K. E., \& Steelman, L. M. (2003). Precursors to mathematical skills: Examining the roles of visual-spatial skills, executive processes, and parenting factors. Applied

Developmental Science, 7(1), 27-38.

15- Clifford, E. (2008). Visualspatial processing and mathematics achievement: The predictive ability of the visual-spatial measures of the Stanford-Binet intelligence scales, and the Wechsler Intelligence Scale for Children. University of South Dakota. ,from(ProQuest) 
literature. Learning Disability

Quarterly, 33(1), 3-18.

21- Reuhkala, M. (2001).

Mathematical skills in ninthgraders: Relationship with visuo-spatial abilities and working memory. Educational Psychology, 21(4), 387-399. solving. Journal of educational psychology, 91(4), 684- 688.

20- Johnson, E. S., Humphrey, M., Mellard, D. F., Woods, K., \& Swanson, H. L. (2010). Cognitive processing deficits and students with specific learning disabilities: A selective meta-analysis of the 